\title{
Subaqueous morphology of Lake Lucerne (Central Switzerland): implications for mass movements and glacial history
}

\author{
Michael Hilbe · Flavio S. Anselmetti • \\ Raymond S. Eilertsen · Louise Hansen • \\ Walter Wildi
}

Received: 1 October 2010/Accepted: 3 August 2011/Published online: 25 November 2011

(C) Swiss Geological Society 2011

\begin{abstract}
Bathymetric data available for Swiss lakes have typically only low to moderate resolution and variable quality, making them insufficient for detailed underwater geomorphological studies. This article presents results of a new bathymetric survey in perialpine Lake Lucerne using modern hydrographic equipment. A digital terrain model (DTM) of the lake floor (raster dataset with $1 \mathrm{~m}$ cell size) covering the Chrüztrichter and Vitznau basins documents signatures of major Holocene mass movements and relics from the glacial history of the lake. Combining the bathymetry data with reflection seismic profiles and an existing event chronology allows investigating the morphology in its geological context. Subaqueous sediment slide scars with sharp headwalls cover large areas on moderately inclined slopes. The particularly large Weggis slide complex, correlated with an historical earthquake (AD 1601), features a $\sim 9 \mathrm{~km}$ long and 4-7 $\mathrm{m}$ high headwall and covers an area of several square kilometers. Large debris cones of prehistoric rockfalls and the deposits of recent rockfall events imaged on the almost flat basin plain
\end{abstract}

Editorial handling: D. Ariztegui and A.G. Milnes.

M. Hilbe $(\square) \cdot$ F. S. Anselmetti

Department of Surface Waters, Eawag, Swiss Federal Institute of Aquatic Science and Technology, 8600 Dübendorf, Switzerland e-mail: michael.hilbe@eawag.ch

R. S. Eilertsen

Geological Survey of Norway (NGU), 9296 Tromsø, Norway

L. Hansen

Geological Survey of Norway (NGU), 7491 Trondheim, Norway

W. Wildi

Institut F.-A. Forel, Université de Genève, 1290 Versoix, Switzerland document mass-movement activity on steep slopes above the lake. Six transverse moraines, visible as subaqueous ridges, as lake-floor lineaments, or only imaged on reflection seismic profiles, indicate a complex glacial-inherited morphology. As many of the documented features result from potentially catastrophic events, high-resolution bathymetry can significantly improve natural hazard assessment for lakeshore communities by extending classical hazard maps to the subaqueous domain.

Keywords Swath bathymetry - Perialpine lakes . Natural hazards - Subaqueous moraines .

Soft-sediment deformation

\section{Introduction}

Knowledge of the landscape morphology on different scales is essential in order to track and understand the various processes shaping the Earth's surface. For the subaqueous environment, where direct observation is difficult, terrain models derived from water-depth measurements (bathymetry) are the basic form of morphological data. In Switzerland, early studies on the submerged morphology of the perialpine lakes have been conducted more than 100 years ago, with the first systematic bathymetric surveys in the framework of the federal "Siegfried Map". They documented the general shape of these deep, often fjord-like basins and also led to the discovery of features on the lake floor such as channellevee complexes on delta slopes in Lake Constance and Lake Geneva (von Salis 1884; Forel 1892) or sublacustrine moraine ridges in Lake Lucerne (Hörnlimann 1886). Early theories on the age of the last glaciation (Heim 1894) or the existence of turbidity currents originating from river 
mouths (Forel 1892) were essentially based on such observations. Subsequent process-oriented investigations have relied on the topographic information provided by the bathymetry data, for instance the direct measurement of the proposed turbidity currents in a submerged channel on the Rhone delta slope in Lake Geneva (Lambert and Giovanoli 1988). The first bathymetric surveys used line soundings taken along profiles, with a density of only a few dozen soundings per $\mathrm{km}^{2}$ (Hörnlimann 1886). In later years the data density was increased to several hundred soundings per $\mathrm{km}^{2}$, most notably through the use of single-beam acoustic echosounders in the second half of the twentieth century (Bertschmann 1953; Lambert 1988). Nevertheless, bathymetric surveys remained labor-intensive and the spatial resolution of the data limited, allowing the systematic exploration of only the most prominent morphological features. To date, no programme for systematic hydrographic surveys of Swiss lakes exists, and available bathymetric data are of variable age and quality, providing at most moderate, often even unknown, data densities and resolutions.

In the past 30 years, new kinds of hydrographic survey equipment capable of substantially higher data density, resolution and accuracy than the traditional sounding methods have become available for marine science (e.g. Allenou and Renard 1978). The bathymetry data obtained with these hydroacoustic instruments ("swath bathymetry systems" or "multibeam echosounders" sensu latu) allow underwater geomorphological studies with a significantly higher level of detail and the identification of numerous smaller-scale features. With respect to traditional methods, current standard swath bathymetry instruments improve the lateral resolution by more than one order of magnitude, with similar or better vertical accuracy. Such high-resolution surveys have become a standard in seafloor research and their widespread use in combination with other methods-including imaging of the sediment subsurface and sampling - has contributed to an improved understanding of seafloor processes in many areas, ranging from volcanic and hydrothermal activity to glacial landforms, delta sedimentation and mass movements (e.g. Fornari et al. 1988; McAdoo et al. 2000; Laberg et al. 2007; Ottesen et al. 2008; L'Heureux et al. 2009; among many others). While these tools have been developed and become standard in the marine environment, their application in lacustrine environments, using portable systems, slowly started only during the past few years, with first case studies in the United States (Lake Tahoe, Crater Lake; Gardner et al. 2000; Bacon et al. 2002) and recently also in perialpine lakes in Italy and France (Bini et al. 2007; Fanetti et al. 2008; Ledoux et al. 2010).

The operation of such state-of-the-art hydrographic equipment was tested for the first time in Switzerland during a pilot project carried out in cooperation with various Swiss federal agencies, exploring the usability of highresolution bathymetry data for scientific and applied purposes in Swiss lakes. Two surveys covered parts of Lake Lucerne (September-October 2007) and Lake Geneva (January-February 2008). The survey on Lake Geneva is outlined in Sastre et al. (2010). The article presented here summarizes results of the first survey on Lake Lucerne (Fig. 1), a perialpine lake with variable basin morphologies, reflecting tectonic predisposition, glacial history and present-day lake floor processes. Previous investigations of its sedimentary record as well as historical accounts document repeated rockfalls and subaqueous mass movements within and around the lake during the Holocene (Siegenthaler et al. 1987; Siegenthaler and Sturm 1991; Schnellmann et al. 2006). While the signatures of these events have been described in sediment cores and in reflection seismic profiles, their morphological expression on the lake floor was only poorly known. The new bathymetry data presented here allow precise mapping and characterization of lake floor features related to mass movements in two basins of the lake (Chrüztrichter and Vitznau basin). In addition, they document the morphology of three large moraine ridges separating the central basins of the lake (Chrüztrichter, Vitznau, Gersau and Treib basins). The combination of the bathymetry data with newly acquired reflection seismic profiles across the Vitznau basin reveals previously unknown features in the deeper subsurface and their relation to the present lake floor morphology, providing new evidence on the glacial history of the basins.

\section{Setting and previous studies}

Lake Lucerne is a perialpine, fjord-type lake of glacial origin located in Central Switzerland (Fig. 1). Its surroundings are situated within the extents of Alpine glaciers at the Last Glacial Maximum, with ice surface elevations reaching 600-1,200 $\mathrm{m}$ above the present lake surface (Bini et al. 2009). Today, seven main basins with depths ranging from 35 to $214 \mathrm{~m}$ cover a total surface area of $114 \mathrm{~km}^{2}$ (BAFU 2008). Two of the subaqueous sills separating the basins are of deltaic origin (present Muota delta near Brunnen; paleodelta near Stansstad). The remaining four sills have been interpreted as moraine ridges based on morphological criteria (e.g. Penck and Brückner 1909). Four proximal basins (Uri, Treib, Gersau, Alpnach) are entirely located within the Helvetic Alpine nappes and in many places surrounded by steep lateral slopes, with neighbouring peaks reaching elevations of more than 1,500 $\mathrm{m}$ above lake level. These basins are fed by four major inflows that account for about $80 \%$ of the lake's water supply (BAFU 2008), resulting in dominantly clastic 


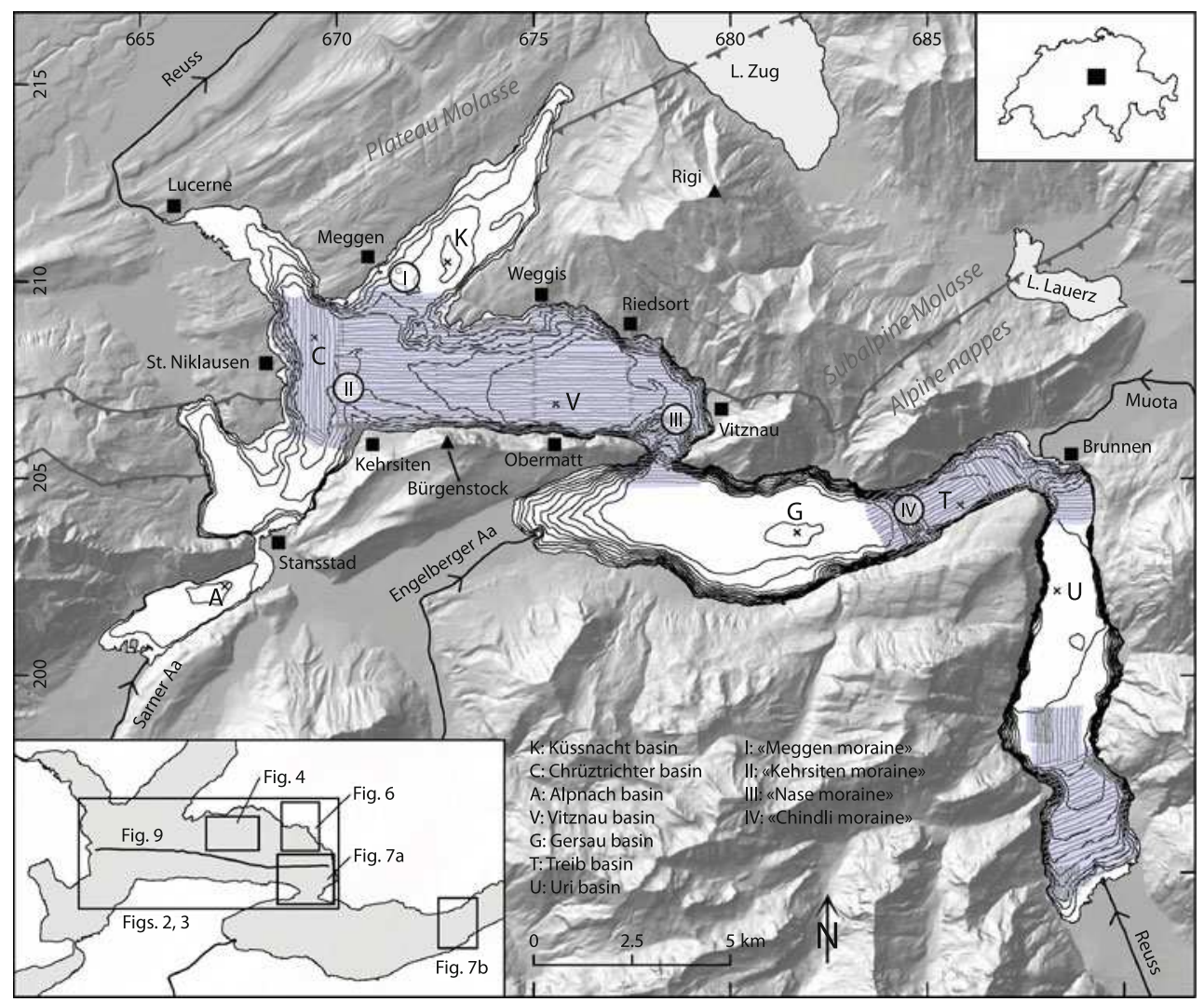

Fig. 1 Lake Lucerne at the northern margin of the Alps in Central Switzerland, with main rivers, neighbouring lakes and tectonic units. A rough bathymetry of the lake is given by contour lines $(20 \mathrm{~m}$ interval, swisstopo DTM 25); the deepest points of the 7 main basins are marked with capital letters, and sills of presumed glacial origin are

sedimentation. The three distal basins (Vitznau, Chrüztrichter, Küssnacht) are located at the Alpine front, surrounded partly by limestone-dominated series of the Helvetic nappes, partly by conglomerates, sandstones and marls of the Molasse (Hantke 2006). Steep rock faces are present along the southern and eastern shores of the Chrüztrichter and Vitznau basins in the Helvetic limestones and Molasse conglomerates. Towards the northwest, the slopes surrounding the lake have a more gentle topography. The distal basins lack major deltas, leading to generally calm sedimentation with only minor amounts of coarse clastic particles (Thevenon and Anselmetti 2007). Holocene sedimentation rates, assessed from undisturbed sections without major event deposits, are in the order of $\sim 1 \mathrm{~m} /$ kyear for basinal areas and typically lower ( $\sim 0.2-0.5 \mathrm{~m} / \mathrm{kyear}$, variable) for gently dipping lateral slopes (Schnellmann et al. 2006; Strasser et al. 2007).

Based on reflection and refraction seismic surveys, Finckh et al. (1984) documented a more than 100 m thick sediment fill in the Vitznau basin and some $200 \mathrm{~m}$ in the Gersau basin, largely consisting of glaciolacustrine deposits, with only the uppermost part being of Holocene age. This upper succession contains numerous slump numbered I to IV. Areas with available high-resolution bathymetry data are shaded, with grey lines showing the individual survey lines for swath bathymetry. Inset Location of other figures. Shaded onshore relief swisstopo DTM25

deposits with related megaturbidites in the deep basins (Siegenthaler et al. 1987). A more detailed seismicstratigraphic analysis based on high-resolution reflection seismic profiles and core data allowed Schnellmann et al. (2006) to construct a detailed catalogue of mass movements in the Chrüztrichter and Vitznau basins, covering the last 15,000 years. The authors identified 19 event horizons connected to one or more subaqueous sediment slides or to rockfalls from steep slopes above the lakeshores. One horizon containing multiple and extensive subaqueous slide and rockfall deposits has been assigned to a strong and historically well-documented earthquake $\left(\mathrm{M}_{\mathrm{W}} \sim 6.2\right)$ that occurred in the area in AD 1601. Similar older horizons with multiple mass-movement deposits have been linked to prehistoric earthquakes (Schnellmann et al. 2002). The distribution of the deposits shows that large subaqueous slope failures preferentially occur on the moderately dipping lateral slopes to the north and west of the study area. Here, slope angles are sufficiently low to allow long-term accumulation of lacustrine sediments, and geotechnical conditions have been favourable for the episodic release of sediments during earthquake shaking (Strasser et al. 2007). Typical failures involve a several metres thick sheet of 
sediment sliding on a stratigraphically defined failure surface, generating a sharp headwall and wedge-shaped massflow deposits that extend from the base of the slope into the basin. These deposits are in many cases directly overlain by a ponding megaturbidite in the deepest part of the basin. At several locations, the basin-plain sediments below the mass-flow deposits are deformed and dissected into slices above a basal décollement, induced by the additional load placed on them by the mass-flow deposits (Schnellmann et al. 2005).

\section{Methods and data}

\subsection{Swath bathymetry}

High-resolution bathymetry data covering most of the distal Chrüztrichter and Vitznau basins as well as other parts of Lake Lucerne (Fig. 1) were acquired during 11 days in September and October 2007, using a GeoAcoustics GeoSwath Plus $125 \mathrm{kHz}$ interferometric sonar installed on the Eawag research vessel "Thalassa". The position and orientation of the boat during the measurements were continuously monitored with a Leica SR 530 GPS receiver with real time kinematic positioning (RTK; swipos GIS/GEO from swisstopo), a TSS DMS-05 inertial navigation system and a TSS SG Brown Meridian gyrocompass. The general pattern of survey lines (Fig. 1) was parallel to the lake axis with a typical spacing of $\sim 100 \mathrm{~m}$. In shallow areas and above steep slopes the spacing was flexibly decreased in order to maintain sufficient coverage of the lake floor. Areas close to the shore were surveyed with shore-parallel lines. Ping rate was variable, depending on water depth and survey line spacing, with typical values ranging between 2 and 5 pings per second, with a normal survey speed of about $2 \mathrm{~m} / \mathrm{s}$.

Acquisition control and data processing were done in the dedicated GeoAcoustics GS+ software package. Input parameters for processing included a horizontally layered sound velocity model for the lake, based on vertical profiles measured daily at locations representative for the surveyed areas using a Valeport 650 sound velocity profiler. Lake level measurements of the station Lucerne of the Swiss basic hydrological monitoring network (BAFU 2008) were used to normalize water depths to the mean lake level (433.6 $\mathrm{m}$ a.s.1.). The depth points were filtered graphically as well as by backscatter amplitude and subsequently binned into a raster bathymetry dataset, which provides a terrain model of the lake floor with a horizontal resolution of $1 \mathrm{~m}$. The estimated accuracy of the depth values is in the range of a few decimetres. Under ideal conditions, however, local depth variations of down to a few centimetres can be resolved. Visualizations and analyses of the bathymetry dataset were performed in standard GIS software. Descriptions and interpretations are based mainly on hillshade images and depth maps (Fig. 2).

In addition to the depth information, the survey system collects data on the amplitude of the received acoustic signals (backscatter intensity), which is controlled by the attenuation in the water column, the local relief of the lake floor (i.e. incidence angle) and also by the "acoustic hardness" of the lake floor, i.e. the contrast of acoustic impedance between water and sediment. Together with the bathymetry, these data thus allow a rough estimation of material properties of the sediment surface, most importantly sediment grain size, with coarser sediments generally yielding higher backscatter values (Beyer et al. 2007). The backscatter intensity data were normalized to 256 values and mosaicked into a single dataset using the GeoAcoustics $G S+$ software (Fig. 3). The processing of the backscatter data is, however, too basic to provide a well-balanced view over the whole survey area. Therefore only relative changes over limited distances should be considered.

\subsection{Reflection seismic profiling}

Geophysical information on the sediment fill of the basins is provided by reflection seismic profiles acquired with two different systems. An existing basinwide dataset of highresolution seismic profiles, recorded between 2000 and 2008 using a $3.5 \mathrm{kHz}$ pinger source/receiver (Schnellmann et al. 2002, 2005, 2006), images the shallow subsurface down to $\sim 50 \mathrm{~m}$. In order to complement this high-resolution dataset with information from the deeper subsurface, five airgun reflection seismic profiles across the study area-four parallel to the valley axis of the Vitznau basin and one perpendicular-were acquired in December 2008. For this survey, a $1 \mathrm{in}^{3}$ Bolt PAR airgun operated at $7 \mathrm{MPa}$ with a shot interval of $4 \mathrm{~s}(\sim 7 \mathrm{~m}$ at average survey speed) was used as seismic source and a single-channel GeoAcoustics hydrophone array (12 elements) with an active length of $3 \mathrm{~m}$ as receiver. Spacing between source and receiver was $\sim 6 \mathrm{~m}$. The data were digitally recorded in SEG-Y format with a flat gain. Processing involved bandpass filtering $(200-800 \mathrm{~Hz})$ and manual removal of spikes by partial muting of traces. A water bottom mute was applied for display of the data. GPS navigation provided a position accuracy of $\sim 5 \mathrm{~m}$.

\section{General characteristics of the basins}

\subsection{Bathymetry}

The bathymetry of the main study area is shown as a colorcoded hillshade map in Fig. 2, together with an interpretation 

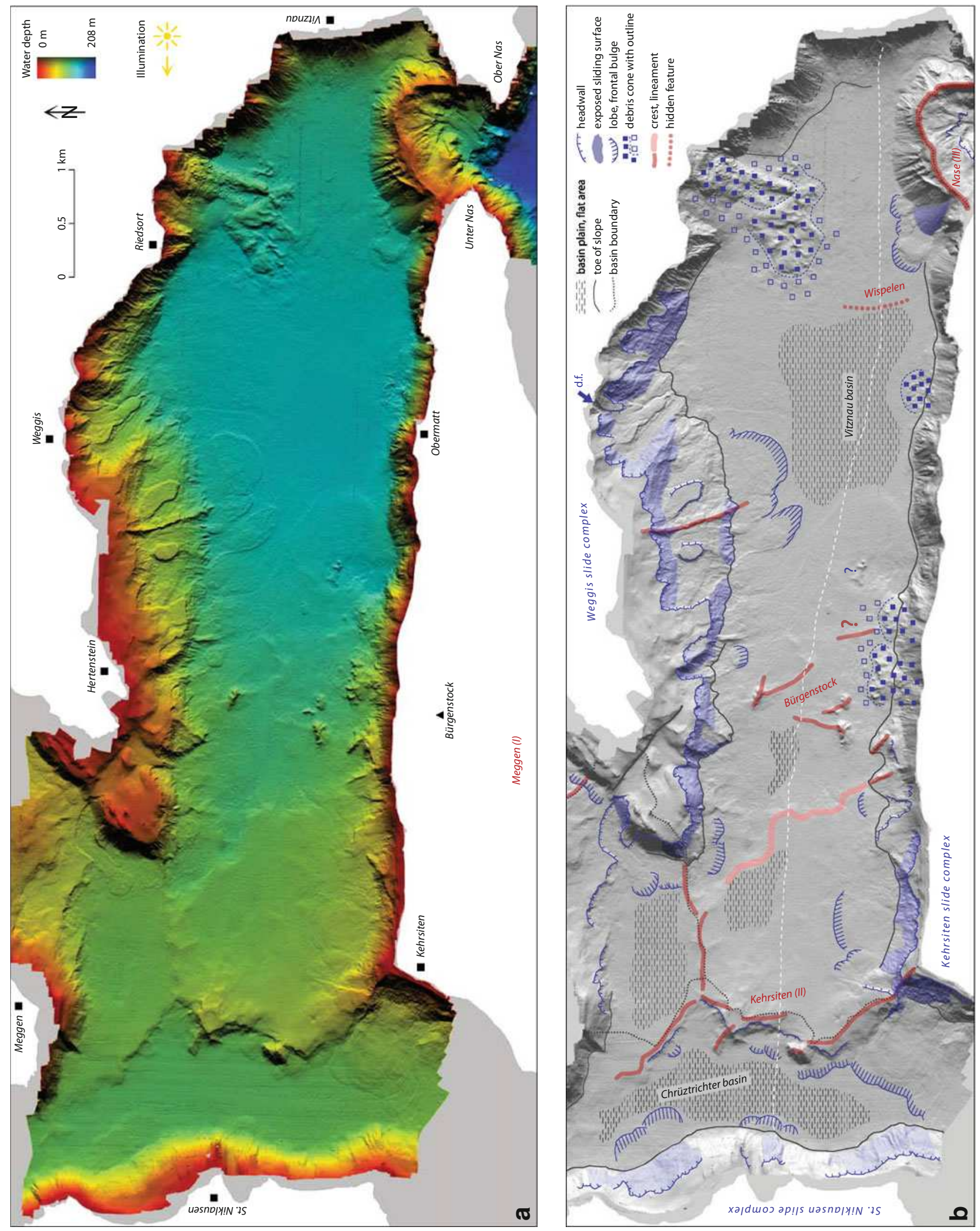

Fig. 2 a Bathymetric map (shaded relief, colour indicating depth) of the Chrüztrichter and Vitznau basins of Lake Lucerne. b Interpretation of observed morphology (see text for a detailed description). Mapped features are grouped by colour. Grey basic topography; blue features related to mass movements; red glacial features. Dashed white line across the basins shows location of seismic profile shown in Fig. 9 


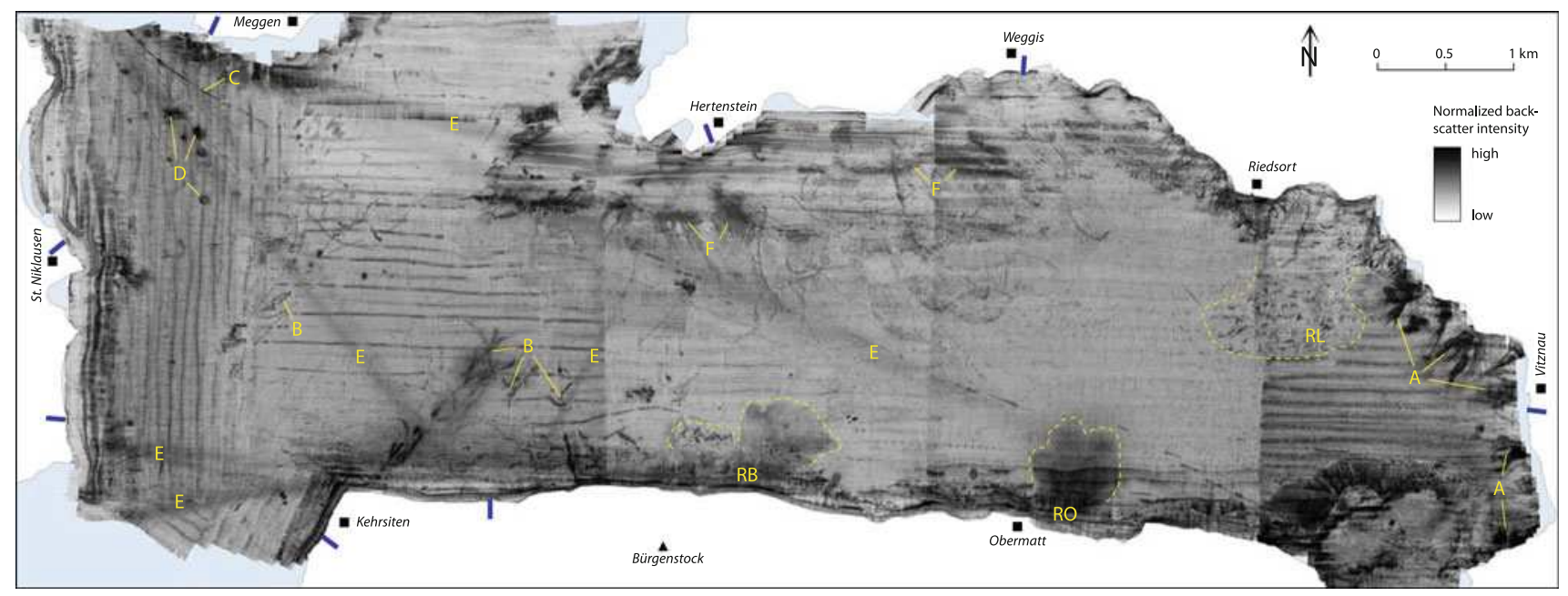

Fig. 3 Distribution of normalized backscatter intensity for Chrüztrichter and Vitznau basins. Yellow labels mark examples of special features discussed in the text, dashed yellow lines outline zones affected by rockfalls (RB: "Bürgenstock rockfalls"; RO: "Obermatt

showing the features discussed in the text. The layout and general topography of the basins have been known since the first bathymetric surveys. They are again outlined here, based on the new data. The main study area extends over two major basins of Lake Lucerne-Chrüztrichter basin and Vitznau basin - that are confined mainly by non-deltaic lateral slopes-mostly bedrock with variable sediment cover-and subaqueous moraine ridges. In addition to the main study area, the ridge separating the Gersau and the Treib basin is documented (Fig. 1). As in other perialpine lakes, the general shape of the basins is elongate and lateral slopes of the basins with typically high slope angles $\left(>5^{\circ}\right.$, up to nearly vertical) are often separated from the lowgradient $\left(<5^{\circ}\right)$ basin floor areas by a distinct break at the toe of the slope (e.g. Adams et al. 2001).

The central part of the $112 \mathrm{~m}$ deep Chrüztrichter basin is situated along the western shore of the lake near St. Niklausen. The basin extends into two large embayments to the northwest and southwest with shallower water depths (Fig. 1; not included in the present survey). A relatively large, elongate basin plain characterizes the central part of the basin, which is bordered by a moderately steep lateral slope to the west (Fig. 2). To the east, a low step ( $\sim 20-30 \mathrm{~m}$ high) rises towards the asymmetric crest that separates Chrüztrichter and Vitznau basins. A $105 \mathrm{~m}$ deep subordinate basin south of Meggen is only separated from the Chrüztrichter basin by a poorly defined, $4 \mathrm{~m}$ high sill and is therefore regarded as a part of the latter.

The $151 \mathrm{~m}$ deep Vitznau basin (Figs. 1,2) extends from Kehrsiten in the west to Vitznau in the east and is separated from the Gersau basin in the southwest by a prominent ridge at the narrow passage between Ober Nas and Unter Nas. It shows an asymmetric cross-section, with a steep rockfalls"; RL: "Lützelau rockfall"). Blue bars at the shoreline indicate positions of landing stages for passenger ships. Note the data artefacts (horizontal and vertical ship tracks, block boundaries) due to insufficient normalization

southern lateral slope and a gently dipping northern slope, which is vertically structured by the occurrence of terraces and steeper zones. East of Weggis, the northern lateral slope is generally steeper, following the morphology above the lake. Several small, steep-fronted deltas originating from local streams cover the lateral slope in the easternmost part of the basin near Vitznau. The basin plain in the deepest part, between Weggis and Obermatt, covers only a relatively small proportion of the total area of the Vitznau basin. The lake floor in the western half of the basin is not flat, but has a pronounced surface topography with subdued steps, ridges and flat areas, overall rising gently towards the crest. The origin of this special morphology is discussed below.

\subsection{Backscatter intensity}

The distribution of backscatter intensity over the main survey area is shown in Fig. 3. Large parts of the basin areas and some regions on the lateral slopes show uniform, low backscatter intensity. This signature is interpreted to correspond to a homogeneous, muddy sediment surface. Higher values are present on and below lateral slopes, often in connection with mass-movement deposits or exposed glacial sediments (discussed below). The small deltas in the easternmost part of the Vitznau basin (see above) also show higher values, probably resulting from coarse-grained sediments deposited on their steep fronts ("A" in Fig. 3). In the basinal areas, isolated zones of elevated backscatter intensity without corresponding bathymetric features can be observed. Most of them probably represent local, manmade changes of the sediment surface. Sharp linear features, common in the western half of the survey area and 
either sinuous ("B" in Fig. 3) or slightly and regularly curved ("C" in Fig. 3), may represent tracks of towed objects or pipelines, respectively. Isolated, round spots ("D" in Fig. 3) probably result from dumping of debris or other material. Diffuse lineaments of slightly elevated backscatter intensity with widths of several hundred metres crossing the whole lake ("E" in Fig. 3) coincide with traditional ship routes that have been in use for more than a century, connecting landing places around the lake. Similar features have been observed in Lake Ontario (North America), where they have been linked to an accumulation of combustion residues-mostly ash particles flushed into the water from steamships-near the sediment surface (Lewis et al. 2000). A similar origin is conceivable for the features observed on Lake Lucerne, where wood- and coalfired steamships were in use from 1837 until the 1930s and increased amounts of coarse charcoal particles have been documented in the sediments (Thevenon and Anselmetti 2007).

\section{Holocene mass movements}

The new bathymetry data document various features related to mass movements on and below lateral slopes, overprinting the general morphology of the basins. Signatures characteristic of two basic types of mass movements-(1) subaqueous slides/mass flows affecting soft lacustrine sediments and (2) rockfalls/rockslides from steep rock faces above the lakeshore-have been mapped using the bathymetry data (Fig. 2). Classification and interpretation of these signatures rely on descriptions of the morphology (elements such as escarpments, bulges or ridges), but also on the identification of "surface textures", i.e. small-scale relief resulting in a distinct appearance of the lake floor in hillshade images. In the following descriptions, the new bathymetry data is complemented with reflection seismic profiles and lithological data from previous studies (Schnellmann et al. 2005, 2006; Strasser et al. 2007) in order to gain a more comprehensive view on the data.

\subsection{Subaqueous sediment slides}

Three types of morphological features on the lake floor are interpreted as diagnostic signatures of subaqueous slides affecting soft lacustrine sediment on lateral slopes of the basins and have been mapped in Fig. 2. Detailed descriptions with examples of these features are given later. More or less sharp escarpments with heights of a few metres and lengths ranging from some hundred metres to several kilometres are interpreted as headwalls. They are often found at the upper slope breaks on lateral slopes and commonly separate areas with different surface textures. A smooth surface with subdued relief above the headwall indicates an intact sediment drape, whereas rough and variable textures below denote the source and transit areas of the mass movements, extending from the headwall to the toe of slope. Within these areas, zones with a distinct, rugged surface texture have been mapped as exposed sliding surfaces. As shown below, those have only minor amounts of soft-sediment cover on a well-defined surface, while other parts of the transit areas may be considerably covered by re-deposited sediments. In the basin areas below many slopes with visible headwalls, lobes with frontal bulges and a typical relief of 1-3 m may reach several hundred metres out into the basins (Fig. 2).

The signatures defined above are present within three large slide complexes in the study area (Fig. 2). The Weggis slide complex is the largest of the three, covering a major part of the northern slope of the Vitznau basin and extending west into the Chrüztrichter basin. Two other complexes are located on the slightly steeper lateral slopes at the western margin of the Chrüztrichter basin (St. Niklausen slide complex) and around Kehrsiten (Kehrsiten slide complex). In addition to these large complexes, smaller slides are present, notably on the slopes of the subaqueous sills between the basins. Altogether, a considerable part of slopes with medium inclinations is affected by slides. On the steep $\left(>25^{\circ}\right)$ lateral slopes in the south and in the east, however, similar indications of subaqueous slides are absent.

The Weggis slide complex, defined by a distinctive single major headwall that runs from Meggen to Riedsort over a distance of $\sim 9 \mathrm{~km}$, with only small interruptions, incorporates the Weggis and Chrüztrichter slides defined by Schnellmann et al. (2005). The following description, which is based primarily on the bathymetry data (Fig. 4) and selected seismic profiles (Fig. 5), focuses on a small area of the slide complex near Weggis, where a variety of different features can be observed (Figs. 1, 4).

The headwall of the Weggis slide complex, located in water depths from 30 to $90 \mathrm{~m}$, is a sharp escarpment with heights between 4 and $7 \mathrm{~m}$ and local slope angles of up to $45^{\circ}$ over distances of a few metres. It separates a smooth, seismically well-layered sediment drape covering an irregular morphology from the exposed sliding surface, which shows a rough surface texture, no acoustic penetration on seismic profiles and elevated backscatter intensity ("F" in Fig. 3; Figs. 4, 5a). This indicates that the exposed sliding surface is not substantially covered by a sediment drape or re-deposited material. However, its variable surface texture suggests that it consists of different types of substrate. While most parts exhibit a directionless roughness pattern and are probably underlain by glacial deposits (Strasser et al. 2007), certain regions are characterized by a 


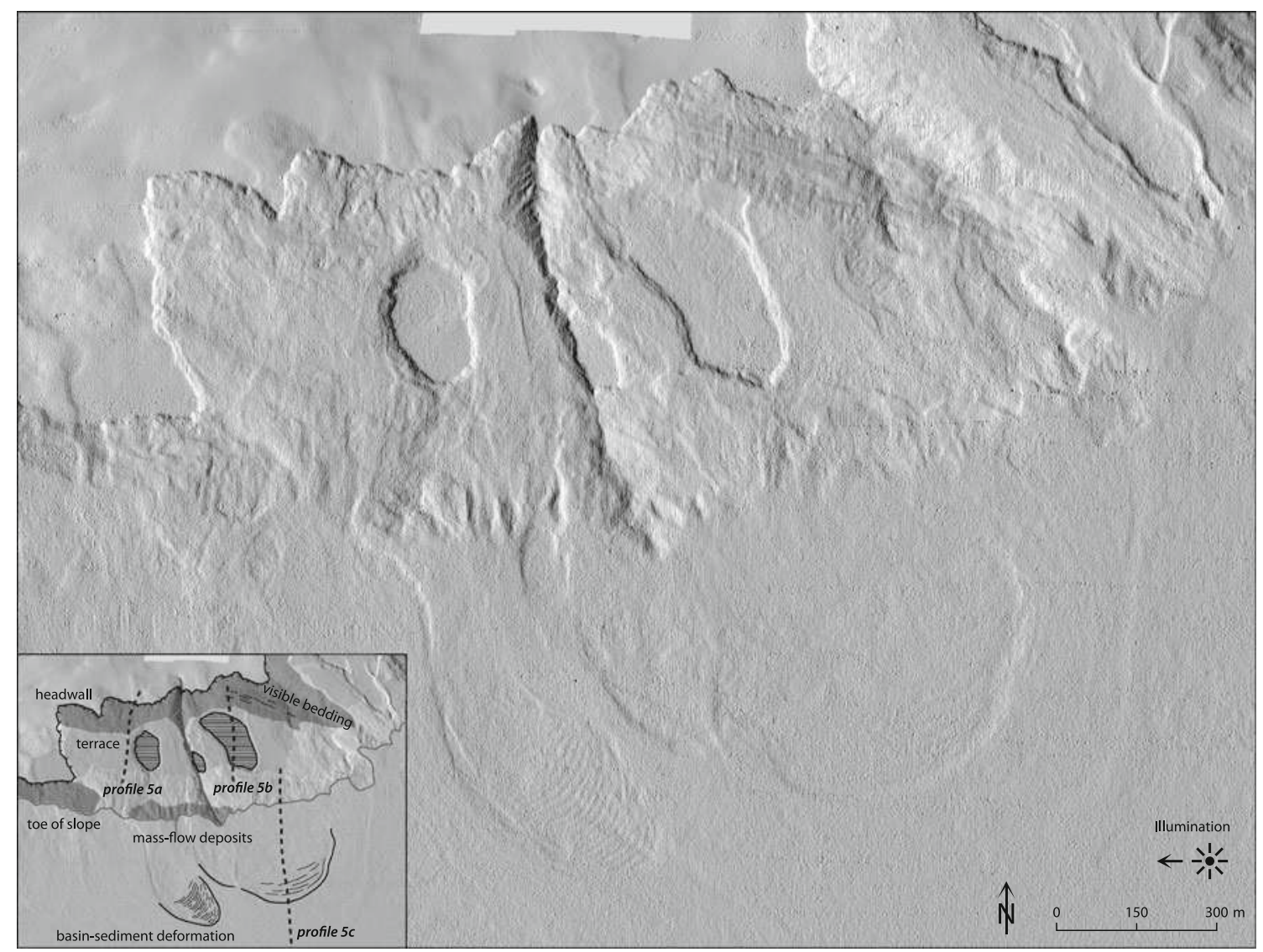

Fig. 4 Shaded relief map of a part of the Weggis slide complex near Weggis village (see Fig. 1 for location). The inset map shows the identified morphological features: shaded exposed sliding surface below headwall; horizontally lined sediment slabs within transit area;

set of parallel linear features that is consistent with the regional dip of the bedrock (Hantke 2006). This pattern presumably represents the bedding of exposed conglomerate banks of the Subalpine Molasse (Fig. 4).

A slope terrace with reduced slope angles $\left(<10^{\circ}\right.$, most parts $<5^{\circ}$ ) in $\sim 90 \mathrm{~m}$ water depth is partly covered by three large slabs of sediment, which are-although situated within the slide scar-apparently unaffected by the sliding and surrounded by a clear escarpment that is similar to the headwall. A seismic section across a slab reveals a generally well-stratified succession without indications of pervasive deformation, but considerably thicker than the sediment drape near the headwall (Figs. 4, 5b). Next to the slabs, the terrace shows a soft, but irregular and not completely smooth surface texture. Similar patterns are observed in other low-gradient regions of the transit area, especially in its lower part. On seismic profiles, this surface texture coincides with the occurrence of bodies with semitransparent to chaotic seismic facies near the sediment surface, which are indicative of mass-flow deposits and which overlie undisturbed, layered sediments in some areas (Figs. 4, 5a). solid lines on the basin plain-deformational bulges. The solid grey line descending on the slope denotes a glacial ridge. The dashed lines indicate the reflection seismic profiles shown on Fig. 5

The mass-flow deposits in the basin area adjacent to the toe of slope form a gently inclined wedge without prominent relief (Fig. 4). Seismic profiles across them show bodies with a typical, semi-transparent to chaotic seismic facies that reach deep into the layered basin sediments and have sharp boundaries to the adjacent and to the underlying basin sediments (Fig. 5c). As documented with sediment cores by Schnellmann et al. (2005), these up to $20 \mathrm{~m}$ thick bodies are composed of the following lithologies: Above a strongly deformed basal part, the main volume consists of packages of undisturbed, layered sediments that are separated by zones with folded and disrupted sediments. In the upper part, the size of the undisturbed packages decreases, and they are overlain by a mass-flow deposit and a megaturbidite, both relatively thin. In the frontal parts of the bodies, the seismic facies is slightly less chaotic and individual slices of internally intact, layered basin sediments can be distinguished on the profiles. These slices are expressed on the lake floor as arrays of almost regularly spaced, arcuate bulges, with heights between 0.5 and $2 \mathrm{~m}$ and spacing ranging from 10 to $40 \mathrm{~m}$, typically around $15 \mathrm{~m}$ (Fig. 4). The most prominent and sometimes only 

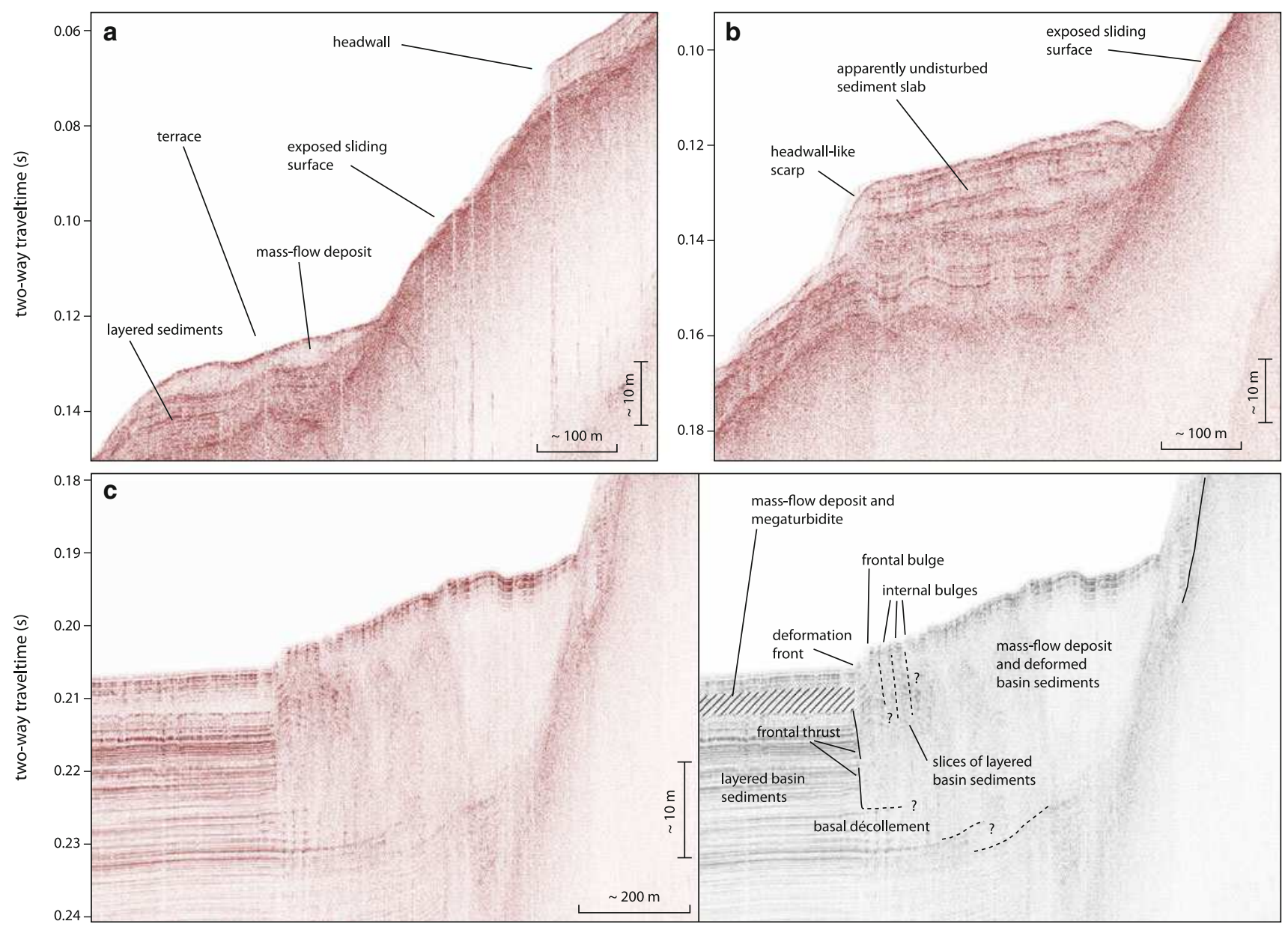

Fig. 5 Reflection seismic profiles (pinger source) across key features of the Weggis slide complex (see Fig. 4 for location). a headwall and terrace; $\mathbf{b}$ sediment slab on terrace; $\mathbf{c}$ toe of slope, mass-flow deposits and deformational bulges. Vertical scales correspond to a sound velocity of $\mathrm{v}_{\mathrm{P}}=1,500 \mathrm{~m} / \mathrm{s}$

deposit originating from a subaerial debris flow locally overprint the headwall and transit area of the Weggis slide complex ("d.f." in Fig. 2; Hilbe et al. 2008; Louis et al. 2008).

The St. Niklausen and Kehrsiten slide complexes show the same principal characteristics as the Weggis slide complex. They are thus not outlined in detail, but basic descriptions and some notable differences are given below. The St. Niklausen slide complex on the western slope has a discontinuous headwall with up to $1.2 \mathrm{~km}$ long segments and partly a smooth appearance (Fig. 2). The source and transit areas are significantly steeper than for the Weggis slide and do not show morphological evidence of major amounts of mass-flow deposits within the slide scar. However, surface textures within the slide scar are softer than for the other two slide complexes. The lobes on the basin plain, defined by pronounced frontal bulges, do not show an internal structure. The generally "smoother" appearance of the features in comparison to the Weggis slide complex indicates that they are covered by a Weggis, where an erosional channel and a mass-flow 
significant post-event sediment drape. This conclusion is supported by reflection seismic profiles, which document a $\sim 2 \mathrm{~m}$ thick drape (Strasser et al. 2007).

The Kehrsiten slide complex affects parts of the Chrüztrichter and Vitznau basins on both sides of a subaqueous ridge (Fig. 2). Headwall segments on both sides are more than $1 \mathrm{~km}$ long and usually separate smooth sediment surfaces above from the roughly textured exposed sliding surfaces below, in a way that is similar to the Weggis slide complex. As indicated by soft surface textures and frontal bulges, mass-flow deposits are present on the lower part of the slope and in the adjacent parts of the basin area. A part of the headwall west of Kehrsiten is located in only $\sim 5 \mathrm{~m}$ water depth, bordering a shore platform (Fig. 2). This part has a slightly different appearance-a rounded edge rather than a sharp step - that possibly results from erosion by current or wave action. Within this part of the headwall, a number of archaeological finds from a Neolithic lakeside settlement have been discovered in cultural layers predating the mass movement and exposed by the sliding (Hügi 2006).

\subsection{Rockfalls}

Subaerial rockslides and rockfalls originating from steep slopes above the lake, represented within the lake by their deposits, are the second type of mass movement shown in Fig. 2. Rockfall deposits are present near the margins of the flat basin areas in the form of isolated or amalgamated debris cones, i.e. zones with a prominent relief (up to more than $10 \mathrm{~m}$ ), a blocky, hummocky surface structure and often characteristic triangular outlines (widening towards the basin). Large rockfall deposits are present at three locations within the lake (Fig. 2): at the toe of the southern slope of the mountain Rigi, near Riedsort $\left(\sim 1.4 \mathrm{~km}^{2}\right.$ within the lake visibly affected), as well as at the southern margin of the Vitznau basin north of Bürgenstock $\left(\sim 0.6 \mathrm{~km}^{2}\right)$ and near Obermatt $\left(\sim 0.4 \mathrm{~km}^{2}\right)$. These areas basically coincide with rockfall cones identified by Schnellmann et al. (2006).

A combination of the bathymetry data with a high-resolution terrain model for the areas above the lake (Fig. 6) provides a comprehensive image of the largest of the three rockfall complexes located near Riedsort, here termed "Lützelau rockfall". The presumed source area and considerable debris masses are located at and below the steep conglomerate cliff north of Lützelau (Hantke 2006). The submerged part of the rockfall deposits is $\sim 700 \mathrm{~m}$ wide near the shoreline and reaches more than $1.5 \mathrm{~km}$ into the basin. Its morphology suggests that it consists of two overlapping but distinct debris cones. A large cone with a triangular outline and a hummocky, but moderately smooth surface structure (A in Fig. 6) is overprinted in its eastern

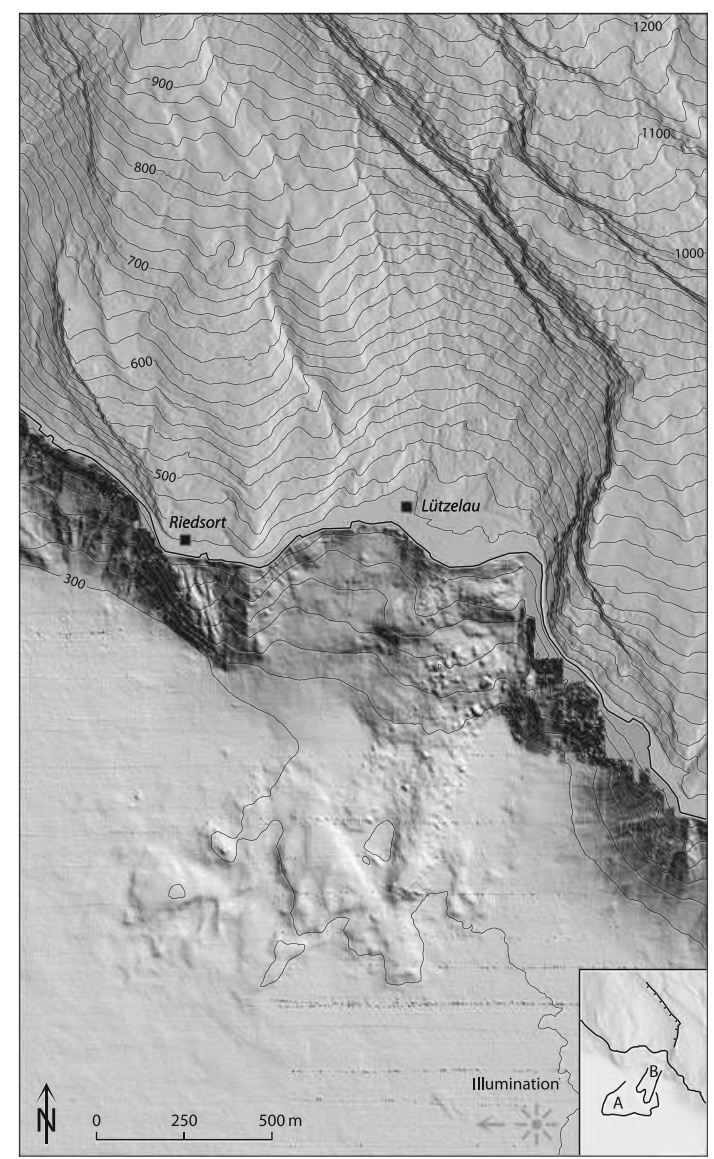

Fig. 6 "Lützelau rockfall" on southern slope of the mountain Rigi, shaded relief generated from combined high-resolution bathymetry data and airborne laser scanning data (swisstopo DTM-AV) for areas above the lake (see Fig. 1 for location). Inset shows positions of identified debris cones and escarpment. Note that shading is scaled differently (underwater areas appear steeper) for bathymetry data and DTM-AV in order to improve the visibility of features

part by a smaller debris cone. The latter has a different surface structure with smaller, but more pronounced "blocks" than the large cone and is split into two narrow lobes in its frontal part (B in Fig. 6). The generally low backscatter intensity with high-intensity spots ("RL" in Fig. 3) suggests that a fine-sediment drape covers most of the coarse rockfall debris.

The rockfall complex north of Bürgenstock consists of two separate debris cones, a slightly larger one with a typical triangular outline and a smaller one located $\sim 500 \mathrm{~m}$ further to the east (Fig. 2). Despite their smaller size, the surface structure and the pattern of backscatter intensity are similar to the deposits of the "Lützelau rockfall". The eastern cone, however, shows some indications of overprinting, with smaller "blocks" visible on top of the cone and elevated backscatter intensity values ("RB" in Fig. 3) in its surroundings. The boundaries of the two debris cones cannot be easily defined due to the occurrence of morphologically similar highs in the basin 
area between Bürgenstock and Hertenstein (Fig. 2). These highs are at least in part related to the glacial morphology of the basins and will be discussed below.

The deposits of the third rockfall complex below the abandoned quarry near Obermatt are significantly less prominent in terms of morphology, with only small-scale irregularities visible on the basin plain (Fig. 2). However, they are characterized by high backscatter intensity over an area which is larger than the visible bathymetric irregularities ("RO" in Fig. 3). This pattern suggests that a large area of the lake floor is covered by exposed coarse rock debris originating from recent rockfall activity in the abandoned quarry. This is documented for the years 1963/1964, 1992 and 2007, and involves a total volume of some $200,000 \mathrm{~m}^{3}$ (Schnellmann et al. 2006; Gemeinde Weggis 2007).

\subsection{Discussion}

As evident from the descriptions above, high-resolution bathymetry allows a detailed analysis of the morphology related to mass movements. Like other perialpine lakes for which high-resolution data are available (e.g. Bini et al. 2007; Ledoux et al. 2010), Lake Lucerne shows signatures of extensive mass-movement activity. The identified key elements of the subaqueous slides in Lake Lucerne-sharp, step-like headwalls, well-defined bedding-parallel sliding surfaces that are partly covered by re-deposited sediments, and frontal bulges in basinal areas-are common for many subaqueous slides. They have been observed in similar forms in other lakes (e.g. Bini et al. 2007), in fjords (e.g. Boe et al. 2003) and also in marine settings such as passive continental margins, there however usually at a much larger scale (e.g. McAdoo et al. 2000; Masson et al. 2010).

To illustrate this, a comparison of the Weggis slide complex with one of the largest and best-known submarine slides, the Storegga slide, offshore western Norway (e.g. Bryn et al. 2005), shows notable morphological similarities of the slide scars, which may indicate similar involved processes. Both slides affect large areas on gently dipping slopes, are outlined by a sharp upper headwall and characterized by bedding-parallel slide surfaces (Haflidason et al. 2004; Bryn et al. 2005), although the dimensions of the Storegga slide are orders of magnitude larger (headwall height $\sim 250 \mathrm{~m}$ compared to $\sim 7 \mathrm{~m}$, affected area $\sim 95,000 \mathrm{~km}^{2}$ compared to $\sim 10 \mathrm{~km}^{2}$ ) and the slope angle is lower $\left(\sim 1^{\circ}\right.$ compared to $\sim 10^{\circ}$; numbers from Bryn et al. 2005). For both slides, small-scale features within the slide scar can be used to map morphological regions of the exposed sliding surface, which consist of different types of substrate and which are partly covered by re-deposited material originating from the slide (Haflidason et al. 2004). The Weggis slide lacks the internal headwalls cutting to deeper stratigraphic levels and the transported blocks found in the Storegga slide scar, which are used as evidence for retrogressive slide propagation. This indicates that the Weggis slide represents a single failure initiated in the steepest parts of the slope near the present headwall, whereas the Storegga slide started in the steepest parts on the lower slope and propagated retrogressively to the upper slope (Bryn et al. 2005). In general, though, the morphological similarities correspond to similar assumed mechanisms for the two slides, i.e. bedding-parallel sliding of soft sediments, caused by the failure of a weak layer due to progressive loading through continuous sedimentation and triggered by an earthquake (Bryn et al. 2005; Strasser et al. 2007).

In the particular situation of Lake Lucerne, where in-depth studies on past mass movements, but only poor knowledge on the morphology have been available, the new bathymetry data reveals additional insights and clarifications. Compared to Schnellmann et al. (2002, 2005), who focused primarily on the deposits of mass movements, fewer but larger subaqueous slides have been identified (Fig. 2). The similarity of the observations and the lateral continuity of the headwall suggest that some of the individual but supposedly coeval slides described by the previous studies (e.g. Weggis and Chrüztrichter slides of Schnellmann et al. 2005) can rather be considered as parts of a larger slide complex resulting from one single failure. Such observations on the morphologically complex lateral slopes are hardly possible using solely reflection seismic profiles, even with a dense grid of lines. The nature of the exposed sliding surface, which is a distinctive and mappable feature of the slide scar (Figs. 2, 4), remains unclear. Strasser et al. (2007) identified the stratigraphic boundary between overconsolidated glacial and underconsolidated late glacial sediments as failure surface and documented limited erosion on this surface within the slide scars. As shown above, this boundary is at least in part coincident with the exposed sliding surface. However, different textures and high backscatter intensity of the latter suggest that its substrate is not uniform, but partly formed by bedrock and partly by glacial deposits. This pattern may represent the initial failure surface, or it may result from (variable) erosion on this surface. For the uppermost parts immediately below the headwall, though, where large areas have been mapped as exposed sliding surfaces, it seems reasonable to assume little to no erosion of the overconsolidated glacial deposits by a sliding stack of soft sediments.

A peculiarity of the Weggis slide complex are the newly discovered sediment slabs within the slide scar, located on a terrace with reduced slope angle (Fig. 4). Morphological arguments indicate that they are intact parts of the original sediment drape that have remained stable: They are single, 
clearly defined bodies without signs of disintegration, with intact internal layering and a smooth surface that resembles the undisturbed drape above the headwall. This hypothesis is supported by slope stability assessments (Strasser et al. 2007; Strasser et al. 2011), which suggest that sediments deposited at the low slope angles on the terrace $\left(<5^{\circ}\right)$ should have remained stable during the event that formed the Weggis slide complex. However, since most of the original sediment drape on the terrace is missing and re-deposited sediments are found instead, it may be assumed that the drape on these parts was either eroded or brought to failure by the descending masses. The remaining slabs, which neither failed nor were overridden, were seemingly bypassed by the sliding mass, protected by their position or by more favourable geotechnical conditions.

Below most of the scars of subaqueous sediment slides, semi-circular lobes have been discovered on the almost flat basin plains. Some of them show small internal bulges, but in most cases where a thicker post-event sediment drape buries the internal bulges, only the lobe with a frontal bulge remains visible. Similar lobes related to mass movements have been documented in other lakes or fjords and seem to be common in settings with an abrupt transition from a relatively steep slope to a flat basin plain (Mazzanti and De Blasio 2010). Different mechanisms have been proposed that attribute the formation of such bulges to the dynamics of a flowing mass or to deformation within a sliding mass (Mazzanti and De Blasio 2010; Moernaut and De Batist 2011). For Lake Lucerne, however, the combination of bathymetry and seismic data (Figs. 4, 5c) shows that the lobes and bulges on the lake floor are the surface expression of deformation structures in the underlying basin sediments, which have been described in detail by Schnellmann et al. (2005). The characteristic bodies identified on seismic profiles (Fig. 5c), coincident with the lobes, consist largely of deformed basin sediments occurring as blocks of layered sediments separated by shear zones. The sharp boundaries separating these bodies from laterally adjacent and underlying undeformed basin sediments are interpreted as frontal thrusts and basal detachments, respectively. The intensity of deformation within the bodies decreases with distance to the base of the slope, so that individual thrust slices of layered sediments, separated by internal thrusts rooted in sediment depths of up to $20 \mathrm{~m}$ and visible on the lake floor as internal bulges, are present near the deformation front. Schnellmann et al. (2005) attributed these structures to loading-induced deformation of a relatively thick pile of basin sediments at the base of lateral slopes during emplacement of the mass-movement deposits. Hence, the visible bulges and lobes on the lake floor do not reflect the geometry of the relatively thin mass-movement deposits-which are wedge-shaped and taper off towards the centre of the basin-but mark the position of the deformation front (frontal bulge) or of individual thrust slices (internal bulges) observed within the basin sediments.

A critical issue that arises when combining the morphology data with the seismic-stratigraphic studies (Schnellmann et al. 2002, 2006) is the correlation of identified morphological surface features and dated events defined with seismic stratigraphy of the basin sediment subsurface. The surface features produced by mass movements are gradually smoothed by continuous sedimentation and possibly other processes such as current-induced sediment relocation. Hence, only events of a limited age range can be identified morphologically. The amount of time during which they remain visible depends on the style and rate of post-event sedimentation. The correlation of surface and subsurface data can be done rigorously for some features in the basin area, where the seismic-stratigraphic event horizons are defined, by identifying the seismicstratigraphic unit responsible for a particular topographic feature on the lake floor. For most of the mapped features, however, especially on the lateral slopes where seismicstratigraphic units are not defined, the correlation is based on (1) a simple comparison with the existing event catalogue, (2) assumed synchronicity, or (3) estimates regarding the "freshness" of the features and the amount of sediment cover. Using this approach, the following correlations of the mapped mass-movement complexes (Fig. 2) with dated event horizons of Schnellmann et al. (2006) are suggested.

The Weggis slide complex with its only weakly altered morphology, largely missing overprinting relations and thin post-event sediment cover is to be assigned to one single event, the historically documented AD 1601 earthquake in Central Switzerland (horizon $\mathrm{C}$ in Schnellmann et al. 2006), with the exception of two minor parts. The westernmost section of the mapped headwall near Meggen, which is covered by a thicker sediment drape and has a smoother appearance, is assigned to a prehistoric earthquake 2,300 cal. years BP (horizon E, op. cit.), and the overprinting by a debris flow near Weggis described above is dated at $\mathrm{AD} 1795$ (horizon $\mathrm{B}$, op. cit.). The mapped features of the St. Niklausen slide complex are assigned to the prehistoric earthquake 2,300 cal. years BP (horizon E, op. cit.). For the Kehrsiten slide complex, most of the visible deposits in the basin areas (frontal bulges) represent the 2,300 cal. years BP event (horizon E, op. cit.), although there has been significant overprinting by mass-flow deposits of the AD 1601 event within the transit area. The weakly altered appearance of the exposed sliding surface and parts of the headwall also suggest a correlation with the AD 1601 event. For the two prehistoric rockfall complexes (north of Bürgenstock and "Lützelau rockfall"), a rigorous correlation of the identified rockfall cones with dated event 
horizons is difficult because the seismic-stratigraphic studies rely on rockfall-derived mass-flow deposits instead of the actual rockfall cones. The two overlapping cones of the large "Lützelau rockfall" correspond to one seismicstratigraphic unit that documents rockfall activity in this area, dated 3,250 cal. years BP (horizon F, op. cit.) and thus were probably formed within one event. The age of the two described rockfall cones below the northern slope of Bürgenstock is not clear. Schnellmann et al. (2006) document six event horizons with rockfall activity in this area, five of them with ages from 6,370 to 12,930 cal. years $\mathrm{BP}$ and a sixth dated AD 1601. The surface structures of the cones with visible large-scale irregularities and smoothedout small-scale features (Fig. 2) suggest that they are covered with a relatively thick post-event drape and formed during the five older events. Smaller "blocks" are only visible within a limited area on top of the eastern cone. They may represent the-relatively limited-overprint by the AD 1601 event, which is also indicated by the higher backscatter intensity for this cone (Fig. 3).

The mapped and described mass movements are relatively rare, but large and potentially catastrophic events. They pose a specific hazard for communities and infrastructure on the often densely populated lakeshores, either directly through descending rock or sediment masses or in the form of impact or tsunami waves (Ward 2001; Heller 2008). In addition, they may indicate strong prehistoric earthquakes (Schnellmann et al. 2002). An integrated approach, combining subaqueous geomorphological mapping with interpretation of reflection seismic profiles and dating of horizons using seismic stratigraphy, allows an estimation of spatial distribution, magnitudes and recurrence times for such disasters. This represents a large step towards the establishment of subaqueous hazard maps, which document a variety of natural hazards that are specific to lakes and which take advantage of lake sediments as natural archives. Within this approach, bathymetry data are used as the basis for initial mapping and are also necessary for advanced steps such as the analysis of subaqueous slope stability (Strasser et al. 2011) and modelling of impact and tsunami waves, therefore being of crucial importance.

\section{Glacial morphology}

The subaqueous ridges separating different basins of Lake Lucerne, already known in the 19th century, are probably the most striking relics from the lake's glacial history. Based on bathymetry data available at that time, Penck and Brückner (1909) identified four major sills within the lake and interpreted them as terminal moraines of successive retreat stages of the last glaciation. From distal to proximal position with respect to the Alps, they are represented by (see roman numerals in Figs. 1, 2): (I) a bulge between Hertenstein and Meggen separating Chrüztrichter and Küsnacht basin, (II) an arcuate crest between Hertenstein and Kehrsiten, separating Chrüztrichter and Vitznau basin as well as by two prominent ridges near Vitznau (III) and near Gersau (IV), separating Vitznau, Gersau and Treib basins. The new high-resolution bathymetry dataset (Fig. 2) images these sills in unprecedented detail and allows a description of their diverse morphologies, ranging from subtle bulges to sharp and high ridges. Moreover, the data reveal a number of glacial features which have not been documented to date.

\subsection{Subaqueous moraine ridges}

The most distal of Penck and Brückner's (1909) "classical" moraines east of Meggen (I; Figs. 1, 2; here informally named "Meggen moraine") is rather a shallow zone without a clearly defined crest, located at the boundary of the survey area. The "Kehrsiten moraine" (II; Figs. 1,2), which forms the asymmetric sill at the western end of the Vitznau basin, has a variable surface expression with strongly changing crest height. In its southernmost part, near Kehrsiten, where significant amounts of till deposits are found on shore (Hantke 2006), it is a broad ridge descending northwards to a dissected central part with two characteristic highs. Further north, two branches are visible as low and smooth bulges in $\sim 100 \mathrm{~m}$ water depth, one running eastwards towards Hertenstein, completing the "classical" moraine postulated by Penck and Brückner (1909), and the other running to the northwest, bordering the deep part of the Chrüztrichter basin and a small subordinate basin east of it (Fig. 2).

In contrast to the sills between the distal basins, the two more proximal sills-the "Nase moraine" separating Vitznau and Gersau basin (III; Figs. 1, 2, 7a) and the "Chindli moraine" between Gersau and Treib basin (IV; Figs. 1, 7b)_are rather simple but voluminous and relatively high ridges with clearly defined crests, but different individual shapes. The "Nase moraine" is a northwardconvex, semi-circular ridge with a crest length of $\sim 2 \mathrm{~km}$ at 24-39 m water depth and a slope height of $\sim 100 \mathrm{~m}$ on both sides. It is located a few $100 \mathrm{~m}$ north of the narrow passage between Unter Nas and Ober Nas, where a bedrock sill formed by limestones of the frontal part of the Helvetic Border Chain (Hantke 2006) creates a steep escarpment towards the deep part of the Gersau basin (Fig. 7a). Average slope angles are $\sim 20^{\circ}$ on the convex northern slope and $\sim 12^{\circ}$ on the southern slope. A subordinate older crest visible on the northern slope below the main crest has been strongly overprinted by the latter and only exists in the outer parts of the moraine arc near the shores ("A" in 

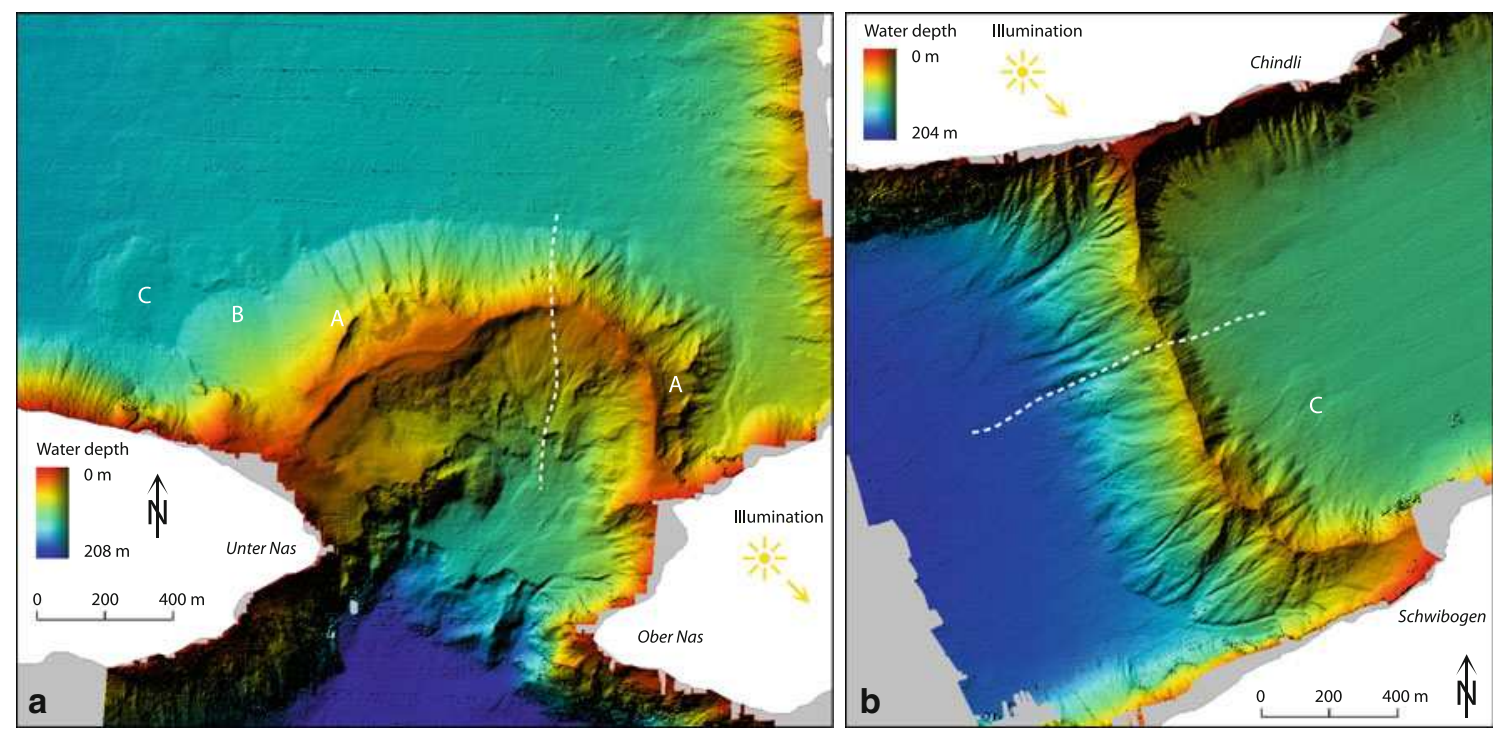

Fig. 7 Bathymetric maps (shaded relief, colour indicating depth) of a "Nase moraine" and b "Chindli moraine", with visible erosional channels, a secondary crest $(A)$, a fan-shaped deposit on the external

slope $(B)$ and traces of mass movements (e.g. $C$ ). Dashed white lines indicate location of seismic profiles in Fig. 8
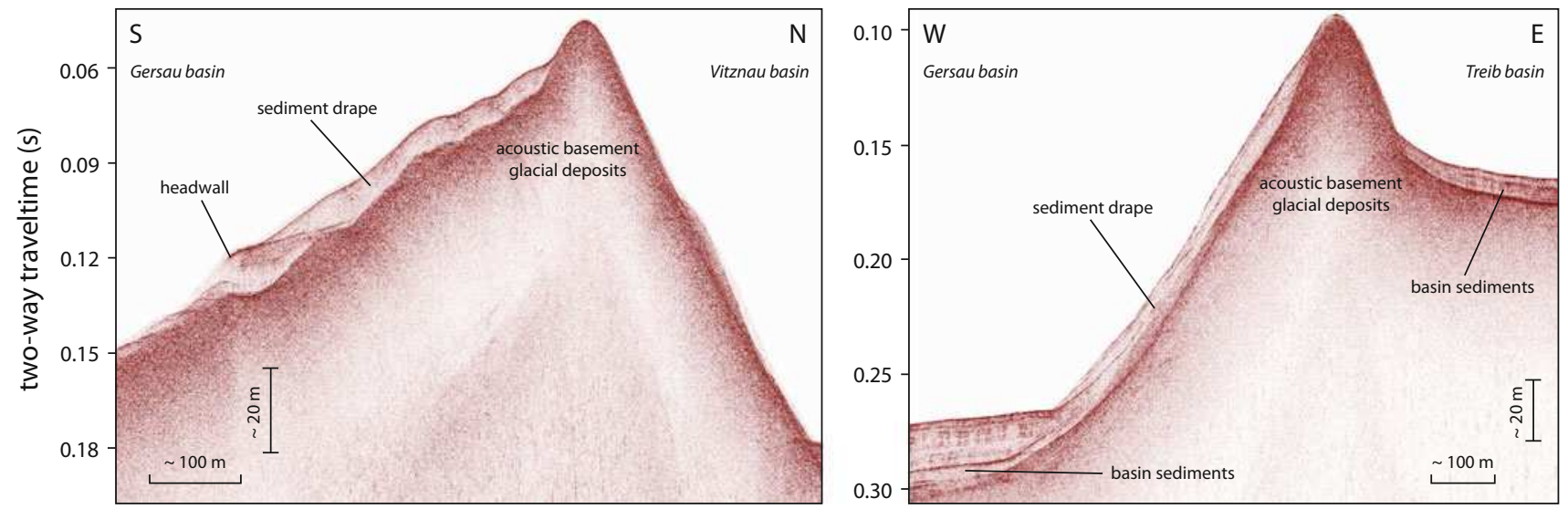

Fig. 8 Reflection seismic profiles (pinger source) across "Nase moraine" (left) and "Chindli moraine" (right; see Fig. 7 for locations). Note the asymmetric distribution of the postglacial sedimentary drape. Vertical scales correspond to a sound velocity of $\mathrm{v}_{\mathrm{P}}=1,500 \mathrm{~m} / \mathrm{s}$

Fig. 7a). Near the western end of the moraine, a fan-shaped deposit with a smooth surface lies on its northern (external) slope ("B" in Fig. 7a). The lacustrine sediment drape of this fan has been removed by a small sediment slide ("C" in Fig. 7a). The "Chindli moraine" is located in a similar configuration $\sim 750 \mathrm{~m}$ west of the narrowest passage between Gersau and Brunnen (Fig. 1). Its $\sim 2 \mathrm{~km}$ long crest at $42-69 \mathrm{~m}$ water depth is pronouncedly straight in the central part and forms a westward-convex bend of $90^{\circ}$ near the southern shore, which has a minor embayment in this area (Fig. 7b). The eastern slope of the ridge is $\sim 70 \mathrm{~m}$ high with an average slope angle of $22^{\circ}$, the western slope reaches a height of more than $130 \mathrm{~m}$ and is slightly less steep with an average slope of $16^{\circ}$.

Reflection seismic profiles across the central parts of the "Nase moraine" and the "Chindli moraine" (Fig. 8, locations shown in Fig. 7) illustrate the asymmetry of the ridges, with the slope on the convex side being steeper for the "Nase moraine", but slightly less steep in the case of the "Chindli moraine". As inferred from seismic profiles (Fig. 8), surface textures identified in the bathymetry data (Fig. 7) and from backscatter intensity data (Fig. 3), the slopes of the ridges have a variable amount of soft lacustrine sediment cover overlying glacial deposits. The latter are supposedly represented by the acoustic basement on the seismic profiles and-where exposed on the lake floorshow high backscatter intensity (Fig. 3) and rough surface textures. Relatively thick sediment drapes $(\sim 10 \mathrm{~m})$ cover the southern slope of the "Nase moraine", which is affected by mass movements with indicative headwalls (Figs. 2, 7a, 8), and the central part of the western slope of the "Chindli moraine". On the northern slope of the "Nase 
moraine" or near the crests, for instance, the glacial deposits are exposed on the lake floor with negligible cover.

The distribution pattern of the cover sediments is presumably controlled by local slope angles and by water currents in the lake. Very steep angles may inhibit sediment accumulation and intermediate angles favour episodic mass movements (Strasser et al. 2007), the deposits of which are visible below some slopes ("C" in Fig. 7). Aeschbach-Hertig et al. (1996) documented currents in the lake, which exchange large volumes of water between the Treib, Gersau and Vitznau basins and may have the potential to inhibit sedimentation or to relocate sediments near the narrowest passages between the basins and on the moraine crests. Despite the overprint by lacustrine sedimentation processes, the appearance of the two proximal moraine ridges with the pervasive pattern of ridges and channels on the slopes supposedly closely resembles the original state. Due to their isolated position, they are not influenced by subaerial erosion or by mass-wasting processes above the shoreline. Sedimentary processes currently observable on the presented data (e.g. scars and deposits of mass movements) are similar to the ones on lateral slopes, affecting only the thin lacustrine sediment drape and resulting in a style of erosion that extends over large areas, but shows only limited incision (Figs. 2, 7). The deeply incised channels on the flanks of the moraine ridges may thus be old features that were shaped during or shortly after their formation. The erosive processes are probably similar to those that are responsible for the overprinting of the secondary crest or the deposition of a sediment fan on the slope of the "Nase moraine" ("A" and "B" in Fig. 7a).

\subsection{Partly buried glacial features}

Apart from the four "classical" moraines, which were already known to some extent before, the new bathymetry dataset reveals several features of glacial origin that have not been documented so far. Within the Vitznau basin several lineaments-bulges or abrupt changes of slope angle - that run preferentially obliquely across the basin are visible (red lines in Fig. 2). Some parts of them emerge from the surrounding smooth lake floor between Hertenstein and Bürgenstock as highs or short crests, with a rugged morphology and high backscatter intensity (Figs. 2, 3). Seismic data combined with bathymetry data reveal that the smooth lineaments are the surface expression of buried features that are larger than suggested by the lake floor morphology and that only emerge from the lacustrine sediment fill at isolated locations. An airgun reflection seismic profile along the axis of the Vitznau basin and across the Chrüztrichter basin (Fig. 9) provides information on the architecture of the deeper sediment subsurface of these basins. On this profile, three seismic facies have been defined for the Vitznau basin, overlying the acoustic basement, which is generally well defined by high-amplitude reflections and shows a pronounced relief with several steep-sided rises. The lowermost facies $\mathrm{C}$ shows undulating, low- to medium-amplitude reflections with modest lateral continuity. It has a special, slightly asymmetric geometry, which is generally ponding, but also produces an upwardconvex step that forms a major lineament on the lake floor (light red line in Fig. 2). The overlying facies B exhibits regular, low-amplitude parallel reflections and a ponding overall geometry. The uppermost facies $\mathrm{A}$ is characterized by medium-amplitude parallel reflections with intercalated

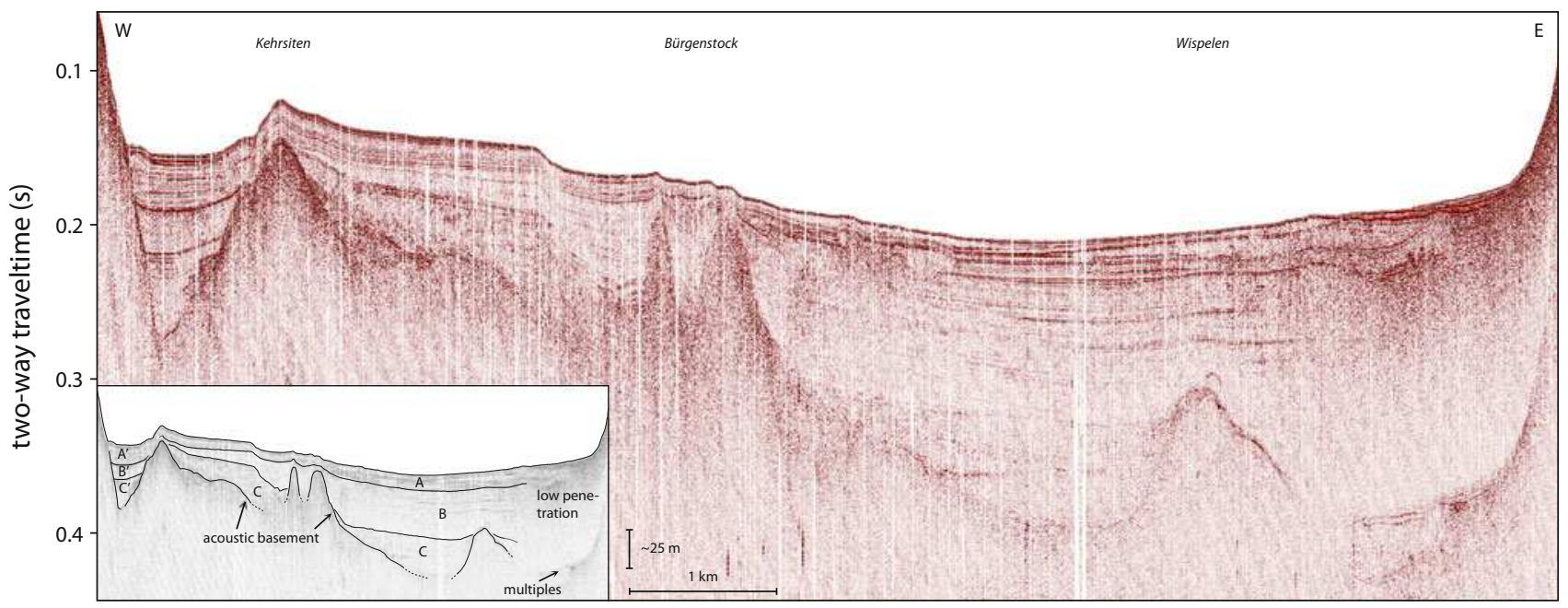

Fig. 9 Airgun reflection seismic profile across Chrüztrichter and Vitznau basins (see Figs. 1, 2 for location), with (inset) the interpretation in terms of seismic facies: $A, B$ and $C$ in the Vitznau basin, and $A^{\prime}, B^{\prime}$ and $C^{\prime}$ in the Chrüztrichter basin. Names given to the three observed highs of acoustic basement correspond to Fig. 2. Vertical scale corresponds to a sound velocity of $\mathrm{v}_{\mathrm{P}}=2,000 \mathrm{~m} / \mathrm{s}$ 
transparent to chaotic bodies and shows a draping geometry. Similar facies $\mathrm{A}^{\prime}, \mathrm{B}^{\prime}$ and $\mathrm{C}^{\prime}$ are present in the Chrüztrichter basin; however, they cannot by directly correlated to the facies in the Vitznau basin across the separating sill.

Considering the previous study by Finckh et al. (1984) as well as seismic-stratigraphic studies from other lakes in high-latitude or perialpine regions (e.g. Giovanoli et al. 1984; Van Rensbergen et al. 1999; Waldmann et al. 2010), the sedimentary succession imaged in Fig. 9 is interpreted as a transition from glacial to post-glacial lacustrine deposits in an overdeepened valley. Facies A represents the current, "draping-type" lacustrine sedimentation with intercalated mass-flow deposits. Facies B and its ponding geometry are interpreted to represent Late Glacial glaciolacustrine sediments deposited by turbiditic underflows, as described in other perialpine lakes (e.g. Lake Zürich: Lister 1984). Facies C, separated from facies B by a major unconformity that has been documented in other lakes as well, probably represents a lower glacio-lacustrine succession, which has been slightly deformed and/or eroded, possibly by a readvancing, "bulldozing" glacier that was in contact with the sediments (Finckh et al. 1984; Lister 1984), resulting in undulating, less continuous reflections and the observed geometry. Till deposits of underlying moraines as well as bedrock are consequently both assigned to the acoustic basement. These denser lithologies are apparently not sufficiently penetrated by the seismic signal; they do not show a visible internal structure and cannot be distinguished.

Based on this model, the steep-sided rises on the surface of the acoustic basement that produce lineaments on the present-day lake floor (Figs. 2, 9) can be interpreted as moraines, possibly associated with bedrock highs and partially or completely buried by the glacio-lacustrine and lacustrine basin fill. Their appearance in the seismic profile (Fig. 9) is similar to that of other documented subaqueous moraines (e.g. Waldmann et al. 2010) and the apparent slope angles of $15^{\circ}-25^{\circ}$ are in agreement with the measured slope angles of the larger proximal moraine ridges. Furthermore the surface structure of the exposed parts is similar to that of the slopes of proximal moraine ridges. Hence, the bathymetric and seismic data (Figs. 2, 9), taken together, may document a previously unknown submerged moraine complex crossing the Vitznau basin between Hertenstein and Bürgenstock, east of the "Kehrsiten moraine" (labeled "Bürgenstock" in Figs. 2, 9). In contrast to the two proximal moraines, this complex is strongly dissected and does not appear to consist of coherent ridges, but rather of several separate highs located within a $\sim 1 \mathrm{~km}$ wide zone, two of which are visible on the seismic profile shown in Fig. 9. An additional positive feature of the acoustic basement is located some $4 \mathrm{~km}$ further east, below the deepest part of the Vitznau basin ("Wispele" in
Figs. 2, 9). It has an asymmetric cross section but lower apparent slope angles of $6^{\circ}$ and $10^{\circ}$ and may also represent a moraine deposit and/or bedrock high. Its bathymetric expression, however, has been smoothed out completely by subsequent glacio-lacustrine and lacustrine sedimentation and no corresponding relief exists on the lake floor today.

\subsection{Discussion}

In analogy to other studies (e.g. Dowdeswell et al. 2008; Waldmann et al. 2010), the succession of subaqueous exposed or partly buried valley-crossing moraines documented with bathymetric and subsurface data can be interpreted as a series of retreat stages of the last glaciation, representing stillstands or small readvances during episodic glacier retreat after the Last Glacial Maximum. Similar studies documenting submerged or buried moraines also exist for other perialpine lakes (e.g. Girardclos et al. 2005). However, any interpretation of the data presented above targeting the involved formation processes and the mode of ice retreat will need to consider the presumably complex ice dynamics in the branched valley system around Lake Lucerne, with confluences and several tributary ice streams from different source areas (Bini et al. 2009). Additionally, a complicated pre-existing topography will influence the number and positions of large transverse moraines, as they tend to form preferentially on bedrock sills (e.g. Shaw 2003; Waldmann et al. 2010), often connected with rapid ice retreat in between (Dowdeswell et al. 2008). The semicircular shape of the "Nase moraine" and its location on a bedrock sill near a narrow passage corresponds to the idea of a terminal moraine that formed during overall retreat at a preferred position that was held by a slightly fluctuating glacier terminus for an extended period, as suggested by the overprinted second crest. The southern part of the "Kehrsiten moraine", on the other hand, with its different shape and its location at the intersection of two main valleys, possibly marks the position of a confluence zone rather than a retreat stage (Buxtorf 1910). However, depending on the timing of ice retreat in the different tributary valleys, the "Kehrsiten moraine" may alternatively represent a terminal moraine of a glacier tongue situated in the Vitznau basin facing an already deglaciated Chrüztrichter basin.

Despite the large volumes of the subaqueous moraine ridges, no notable continuations of the "Nase moraine" and "Chindli moraine" exist on the steep slopes above the lake. For the "Kehrsiten moraine" however, an extensive till deposit around Kehrsiten forms the continuation of the subaqueous ridge up to an elevation of $\sim 200 \mathrm{~m}$ above the present lake level (Buxtorf et al. 1916). Generally, the correlation of the subaqueous ridges with moraines found in terrestrial environments in other valleys and the definition of retreat stages seems problematic if the distribution 
of subaqueous moraines is significantly controlled by the bedrock topography within the overdeepened valleys. The situation found in Lake Lucerne, with $\sim 6$ submerged transverse moraines documented within less than $20 \mathrm{~km}$ along the valley axis, is probably not unique to this area, and it can be hypothesized that similar features exist within the sediment fill of other perialpine valleys.

For a detailed and comprehensive investigation of the past glacial processes in the lake basins, the available data are currently insufficient. For instance, the internal structure of the large ridges and individual highs, the main lithologies of which they are composed, and the bedrock topography in the basins and below the ridges or highs are so far unknown. Such data are needed to investigate the nature of the described features, whether they are large accumulations of glacial deposits or merely the expression of bedrock topography, and whether they are composed of proglacial deposits that has been relocated by an advancing glacier as "push moraines" (Bennett 2001) or represent purely depositional features formed at a glacier front similar to "grounding-line fans" (Powell 1990). This information will be necessary to understand the different observed morphologies-ranging from coherent ridges, such as the "Chindli moraine" or the "Nase moraine", over dissected ridges, such as the central part of the "Kehrsiten moraine", to fragmentary features, such as the individual highs in the western part of the Vitznau basin-that may have been shaped either by glacial processes in contact with the glacier tongue or by periglacial processes only after ice retreat.

\section{Conclusion}

The application of state-of-the-art hydrographic survey equipment - a novelty for Swiss lakes - is a major advance compared to "traditional" survey methods and makes detailed underwater geomorphological studies possible. The new high-resolution bathymetric dataset acquired for parts of Lake Lucerne documents numerous previously unknown morphological features. Combining these data with reflection seismic studies of the sediment subsurface and with a dated event catalogue (Schnellmann et al. 2006) permits a geological interpretation of the lake floor morphology and new insights into the history of the lake. Specifically, several observations concerning mass movements and glacial landforms within the lake are made. As many documented mass movements are related to natural hazards specific to lakeshore communities, the new data allow expanding classical, geomorphological hazard maps to underwater areas.
Subaqueous sediment slides affect fine-grained lacustrine sediments draping gently dipping lateral slopes of the distal Chrüztrichter and Vitznau basins. Their characteristic signatures include clearly defined headwalls with heights between 4 and $7 \mathrm{~m}$ and lengths of up to several kilometers as well as lobes in the basin areas, defined by semi-circular bulges. Within the transit areas of the slides, zones with a variable cover of mass-flow deposits as well as zones with an exposed sliding surface under a thin post-event drape exist. The latter are common on steeper parts of the slopes adjacent to the headwalls, with glacial deposits or Molasse bedrock as their substrate.

The three large subaqueous slide complexes identified in the study area result essentially from single events, although some overprinting by later mass movements and remnant features of previous events are documented. Two slide complexes (St. Niklausen and Kehrsiten) are correlated with a postulated prehistoric earthquake 2,300 cal. years BP, one (Weggis) with a historical earthquake in $\mathrm{AD}$ 1601 (Schnellmann et al. 2006). Features assigned to these two events can be tentatively distinguished based on their appearance, a result of continuous smoothing of the morphology by a growing sediment drape. Older subaqueous slides do not have a clear morphological expression as their corresponding features have been buried or obliterated by subsequent larger events. Large debris cones that document rockfalls from rock faces above the lake have a more pronounced relief and may remain visible for longer time spans.

Subaqueous and partly buried moraines, characterized as topographic highs of the lake floor, reflect the glacial history of the lake. Two moraines located in more proximal positions are relatively simple ridges with visible heights of more than $100 \mathrm{~m}$, well preserved due to limited erosion and overprinting. In the western part of the Vitznau basin the most common glacial signatures are less spectacular. They consist of partly or completely buried moraines, visible either as isolated highs protruding from the smooth surrounding lake floor or only as an extensive pattern of bulges or slight changes of slope angle on the lake floor. Their geometry seems complex and is poorly constrained by the available data, as most parts are hidden below lacustrine and glacio-lacustrine sediments. Between the distal Küssnacht basin and the proximal Treib basin, about six transverse moraines or moraine complexes exist. While an extensive genetic interpretation regarding the ice retreat would be disputable, the presented data suggests that the architecture of the sediment fill of overdeepened perialpine valleys varies significantly along the valley axis, possibly influenced by standstills or short readvances during overall retreat. 
Acknowledgments Funding for the bathymetric survey was provided by the Swiss Federal Office of Topography (swisstopo), the Federal Office for the Environment (FOEN), the Federal Department of Defense, Civil Protection and Sport (DDPS) and the Fachstelle für Archäologie, Canton of Nidwalden. Alois Zwyssig, Matteo Bonalumi and Oddbjörn Totland are gratefully acknowledged for their help during the fieldwork. Constructive comments by reviewers J. Goff and C. Gebhardt as well as editors D. Ariztegui and A.G. Milnes helped to improve the manuscript. Swisstopo kindly provided the GPS positioning equipment and access to their swipos GIS/GEO service.

\section{References}

Adams, E. W., Schlager, W., \& Anselmetti, F. S. (2001). Morphology and curvature of delta slopes in Swiss lakes: lessons for the interpretation of clinoforms in seismic data. Sedimentology, 48, 661-679.

Aeschbach-Hertig, W., Kipfer, R., Hofer, M., Imboden, D. M., \& Baur, H. (1996). Density-driven exchange between the basins of Lake Lucerne (Switzerland) traced with the $3 \mathrm{H}-3 \mathrm{He}$ method. Limnology and Oceanography, 41, 707-721.

Allenou, J.-P., \& Renard, V. (1978). Le sea-beam, sondeur à faisceaux multiples du navire océanographique "Jean Charcot". Publications du Centre National pour l'exploitation des oceans, Rapport Scientifique et Technique (Vol. 37). Brest: Centre Océanologique de Bretagne.

Bacon, C. R., Gardner, J. V., Mayer, L. A., Buktenica, M. W., Dartnell, P., Ramsey, D. W., et al. (2002). Morphology, volcanism and mass wasting in Crater Lake, Oregon. Geological Society of America Bulletin, 114, 675-692.

BAFU (2008). Hydrologisches Jahrbuch der Schweiz, 2007. UmweltWissen Nr. 0824. Bern: Bundesamt für Umwelt.

Bennett, M. R. (2001). The morphology, structural evolution and significance of push moraines. Earth-Science Reviews, 53, 197-236.

Bertschmann, S. (1953). Seetiefenmessungen mit einem EcholotApparat und ihre Ergebnisse. Reihe B: Angewandte GeodäsieVeröffentlichung Nr. 10, München: Deutsche Geodätische Kommission.

Beyer, A., Chakraborty, B., \& Schenke, H. W. (2007). Seafloor classification of the mound and channel provinces of the Porcupine Seabight: An application of the multibeam angular backscatter data. International Journal of Earth Sciences, 96, 11-20.

Bini, A., Buoncristiani, J.-F., Couterrand, S., Ellwanger, D., Felber, M., Florineth, D., et al. (2009). Switzerland during the Last Glacial Maximum, 1:500000. Wabern: Swiss Federal Office of Topography.

Bini, A., Corbari, D., Falletti, P., Fassina, M., Perotti, C. R., \& Piccin, A. (2007). Morphology and geological setting of Iseo Lake (Lombardy) through multibeam bathymetry and high-resolution seismic profiles. Swiss Journal of Geosciences, 100, 23-40.

Boe, R., Rise, L., Blikra, L. H., Longva, O., \& Eide, A. (2003). Holocene mass-movement processes in Trondheimsfjorden, Central Norway. Norwegian Journal of Geology, 81, 3-22.

Bryn, P., Berg, K., Forsberg, C. F., Solheim, A., \& Kvalstad, T. J. (2005). Explaining the Storegga slide. Marine and Petroleum Geology, 22, 11-19.

Buxtorf, A. (1910). Erläuterungen zur geologischen Karte des Bürgenstocks, Spezialkarte Nr. 27a mit Profiltafel 27b. Basel: Buchdruckerei Emil Birkhäuser, Basel.

Buxtorf, A., Tobler, A., Niethammer, G., Baumberger, E., Arbenz, P., \& Staub, W. (1916). Geologische Vierwaldstättersee-Karte 1:50000. Schweizerische Geologische Kommission. Winterthur: Kartographia A.-G.
Dowdeswell, J. A., Ottesen, D., Evans, J., O Cofaigh, C., \& Anderson, J. B. (2008). Submarine glacial landforms and rates of ice-stream collapse. Geology, 36, 819-822.

Fanetti, D., Anselmetti, F. S., Chapron, E., Sturm, M., \& Vezzoli, L. (2008). Megaturbidite deposits in the Holocene basin fill of Lake Como (Southern Alps, Italy). Palaeogeography, Palaeoclimatology, Palaeoecology, 259, 323-340.

Finckh, P., Kelts, K., \& Lambert, A. (1984). Seismic stratigraphy and bedrock forms in perialpine lakes. Geological Society of America Bulletin, 95, 1118-1128.

Forel, F.-A. (1892). Le Léman. Monographie limnologique, Tome premier. Lausanne: Rouge.

Fornari, D. J., Garcia, M. O., Tyce, R. C., \& Gallo, D. G. (1988). Morphology and structure of Loihi Seamount based on Seabeam sonar mapping. Journal of Geophysical Research, 93, 1522715238 .

Gardner, J. V., Mayer, L. A., \& Hughes Clarke, J. E. (2000). Morphology and processes in Lake Tahoe (California-Nevada). Geological Society of America Bulletin, 112, 736-746.

Gemeinde Weggis. (2007). Felsstürze Obermatt, Information 21 Sept 2007.

Giovanoli, F., Kelts, K., Finckh, P., \& Hsü, K. J. (1984). Geological framework, site survey and seismic stratigraphy. In K. J. Hsü \& K. R. Kelts (Eds.), Quaternary geology of Lake Zurich: An interdisciplinary investigation by deep-lake drilling (Vol. 13, pp. 5-20). Contributions to Sedimentology. Stuttgart: E. Schweizerbart'sche Verlagsbuchhandlung

Girardclos, S., Fiore, J., Rachoud-Schneider, A.-M., Baster, I., \& Wildi, W. (2005). Petit-Lac (western Lake Geneva) environment and climate history from deglaciation to the present: a synthesis. Boreas, 34, 417-433.

Haflidason, H., Sejrup, H. P., Nygard, A., Mienert, J., Bryn, P., Lien, R., et al. (2004). The Storegga slide: architecture, geometry and slide development. Marine Geology, 213, 201-234.

Hantke, R. (2006). Rigi mit Nordteil von Blatt Beckenried, mit Erläuterungen. Geologischer Atlas der Schweiz 1:25000, Nr. 116. Wabern: Bundesamt für Landestopographie.

Heim, A. (1894). Ueber das absolute Alter der Eiszeit. Vierteljahrsschrift der Naturforschenden Gesellschaft in Zürich, 39, 180-186.

Heller, V. (2008). Landslide generated impulse waves: Prediction of near field characteristics. Mitteilungen 204, Versuchsanstalt für Wasserbau, Hydrologie und Glaziologie (VAW), ETH Zürich.

Hilbe, M., Anselmetti, F. S., Eilertsen, R. S., \& Hansen, L. (2008). Spuren von Massenbewegungen auf dem Grund des Vierwaldstättersees bei Weggis: Die Ereignisse von 1601 und 1795. Bulletin für angewandte Geologie, 13, 83-85.

Hörnlimann, J. (1886). Ueber Seetiefenmessungen. Schweizerische Bauzeitung, 7, 133-134.

Hügi, U. (2006). Stansstad NW-Kehrsiten, Neolithische Seeufersiedlungen am Alpennordrand. Jahrbuch Archäologie Schweiz, $89,7-23$.

L'Heureux, J.-S., Hansen, L., \& Longva, O. (2009). Development of the submarine channel in front of the Nidelva River, Trondheimsfjorden, Norway. Marine Geology, 260, 30-44.

Laberg, J. S., Eilertsen, R. S., Salomonsen, G. R., \& Vorren, T. O. (2007). Submarine push moraine formation during the early Fennoscandian Ice Sheet deglaciation. Quaternary Research, 67, 453-462.

Lambert, A. (1988). Seegrundvermessungen im Lago Maggiore: Das Wachstum des Maggia-und Ticino/Verzasca-Deltas von 1890 bis 1986. wasser, energie, luft, 80, 21-28.

Lambert, A., \& Giovanoli, F. (1988). Records of riverborne turbidity currents and indications of slope failures in the Rhone delta of Lake Geneva. Limnology and Oceanography, 33, 458-468.

Ledoux, G., Lajeunesse, P., Chapron, E., \& St-Onge, G. (2010). Multibeam bathymetry investigations of mass movements in 
Lake Le Bourget (NW Alps, France) using a portable platform. In D. C. Mosher, et al. (Eds.), Submarine mass movements and their consequences, 4th International Symposium (pp. 423-434). Dordrecht: Springer.

Lewis, C. F. M., Mayer, L. A., Mukhopadhyay, P. K., Kruge, M. A., Coakley, J. P., \& Smith, M. D. (2000). Multibeam sonar backscatter lineaments and anthropogenic organic components in lacustrine silty clay, evidence of shipping in western Lake Ontario. International Journal of Coal Geology, 43, 307-324.

Lister, G.S. (1984). Lithostratigraphy of Zübo sediments. In K. J. Hsü \& K. R. Kelts (Eds.), Quaternary geology of Lake Zurich: An interdisciplinary investigation by deep-lake drilling (Vol. 13, pp. 31-58). Contributions to Sedimentology. Stuttgart: E. Schweizerbart'sche Verlagsbuchhandlung

Louis, K., Bänninger, P., Luterbacher, J., \& Zwyer, T. (2008). Der Schuttstrom vom 15./16. Juliin 1795 Weggis-Rekonstruktion des Ereignisses und Beurteilung des vorhandenen Gefahrenpotentials. Bulletin für angewandte Geologie, 13, 55-81.

Masson, D. G., Wynn, R. B., \& Talling, P. J. (2010). Large landslides on passive continental margins: Processes, hypotheses and outstanding questions. In D. C. Mosher, et al. (Eds.), Submarine mass movements and their consequences, 4th International Symposium (pp. 153-165). Dordrecht: Springer.

Mazzanti, P., \& De Blasio, F. V. (2010). Peculiar morphologies of subaqueous landslide deposits and their relation to flow dynamics. In D. C. Mosher, et al. (Eds.), Submarine mass movements and their consequences, 4th International Symposium (pp. 141-151). Dordrecht: Springer.

McAdoo, B. G., Pratson, L. F., \& Orange, D. L. (2000). Submarine landslide geomorphology, US continental slope. Marine Geology, 169, 103-136.

Moernaut, J., \& De Batist, M. (2011). Frontal emplacement and mobility of sublacustrine landslides: Results from morphometric and seismostratigraphic analysis. Marine Geology, 285, 29-45.

Ottesen, D., Dowdeswell, J. A., Denn, D. I., Kristensen, L., Christiansen, H. H., Christensen, O., et al. (2008). Submarine landforms characteristic of glacier surges in two Spitzbergen fjords. Quaternary Science Reviews, 27, 1583-1599.

Penck, A., \& Brückner, E. (1909). Die Alpen im Eiszeitalter. Zweiter Band: Die Eiszeiten in den nördlichen Westalpen. Leipzig: C.H. Tauchnitz.

Powell, R. D. (1990). Glacimarine processes at grounding-line fans and their growth to ice-contact deltas. In J. A. Dowdeswell \& J. D. Scourse (Eds.), Glacimarine environments: Processes and sediments (Vol. 53, pp. 53-73) (Vol. 53, pp. 53-73). London: Geological Society Special Publication.

Sastre, V., Loizeau, J.-L., Greinert, J., Naudts, L., Arpagaus, P., Anselmetti, F., et al. (2010). Morphology and recent history of the Rhone River delta in Lake Geneva (Switzerland). Swiss Journal of Geosciences, 103, 33-42.

Schnellmann, M., Anselmetti, F. S., Giardini, D., \& McKenzie, J. A. (2005). Mass movement-induced fold-and-thrust belt structures in unconsolidated sediments in Lake Lucerne (Switzerland). Sedimentology, 52, 271-289.

Schnellmann, M., Anselmetti, F. S., Giardini, D., \& McKenzie, J. A. (2006). 15,000 Years of mass-movement history in Lake Lucerne: Implications for seismic and tsunami hazards. Eclogae geologicae Helvetiae, 99, 409-428.

Schnellmann, M., Anselmetti, F. S., Giardini, D., McKenzie, J. A., \& Ward, S. N. (2002). Prehistoric earthquake history revealed by lacustrine slump deposits. Geology, 30, 1131-1134.

Shaw, J. (2003). Submarine moraines in Newfoundland coastal waters: Implications for the deglaciation of Newfoundland and adjacent areas. Quaternary International, 99-100, 115-134.

Siegenthaler, C., Finger, W., Kelts, K., \& Wang, S. (1987). Earthquake and seiche deposits in Lake Lucerne, Switzerland. Eclogae geologicae Helvetiae, 80, 241-260.

Siegenthaler, C., \& Sturm, M. (1991). Slump induced surges and sediment transport in Lake Uri, Switzerland. Verhandlungen Internationale Vereinigung für theoretische und angewandte Limnologie, 24, 955-958.

Strasser, M., Hilbe, M., \& Anselmetti, F. S. (2011). Mapping basinwide subaquatic slope failure susceptibility as a tool to assess regional seismic and tsunami hazards. Marine Geophysical Researches, 32, 331-347.

Strasser, M., Stegmann, S., Bussmann, F., Anselmetti, F. S., Rick, B., \& Kopf, A. (2007). Quantifying subaqueous slope stability during seismic shaking: Lake Lucerne as model for ocean margins. Marine Geology, 240, 77-97.

Thevenon, F., \& Anselmetti, F. S. (2007). Charcoal and fly-ash particles from Lake Lucerne sediments (Central Switzerland) characterized by image analysis: anthropologic, stratigraphic and environmental implications. Quaternary Science Reviews, 26, 2631-2643.

Van Rensbergen, P., De Batist, M., Beck, C., \& Chapron, E. (1999). High-resolution seismic stratigraphy of glacial to interglacial fill of a deep glacigenic lake: Lake Le Bourget, Northwestern Alps, France. Sedimentary Geology, 128, 99-129.

Von Salis, A. (1884). Die Tiefenmessungen im Bodensee. Schweizerische Bauzeitung, 3, 127.

Waldmann, N., Ariztegui, D., Anselmetti, F. S., Coronato, A., \& Austin, J. A., Jr. (2010). Geophysical evidence of multiple glacier advances in Lago Fagnano $\left(54^{\circ} \mathrm{S}\right)$, southernmost Patagonia. Quaternary Science Reviews, 29, 1188-1200.

Ward, S. N. (2001). Landslide tsunami. Journal of Geophysical Research, 106, 11201-11215. 